\title{
Probleme Dayalı Harmanlanmış Öğrenme Ortamının Etkililiğinin ve Öğrencilerin
} Tutumlarının İncelenmesi

\section{The Investigation of the Effectiveness of the Problem-Based Blended Learning Environment and} Students' Attitudes

\section{Emrah Hï̆̆DE ${ }^{1}$, Hilal AKTAMIŞ²}

\begin{abstract}
Öz
Bu çalışma hem yüz yüze hem de çevrimiçi öğrenme ortamlarının özelliklerinden yola çıkarak hazırlanan probleme dayalı harmanlanmış öğrenme ortamının etkililiğini ve öğrenci tutumlarını belirlemek üzere gerçekleştirilmiştir. Çalışma grubunu, bir devlet üniversitesinde fen bilgisi öğretmenliği programında 2019-2020 öğretim yılı bahar dönemindeki 42 (28 kadın 14 erkek) üçüncü sınıf öğrencisi oluşturmaktadır. Öğrencilere dönemin ilk yarısında yüz yüze ikinci yarısında uzaktan eğitim olacak şekilde probleme dayalı fen öğretim laboratuvar dersi deneysel uygulama olarak verilmiştir. Deneysel uygulama sonunda Web Tabanlı Probleme Dayalı Öğrenme Tutum Ölçeği ve Harmanlanmış Öğrenme Ortamları Ölçeği aracılı̆̆ıyla veriler elde edilmiştir. Ayrıca öğrencilerin pandemi dönemindeki eğitim sürecine yönelik olumlu ve olumsuz görüşleri açı uçlu sorular aracılığıyla yazılı olarak öğrencilerden toplanmıștır. Çalışma sonunda öğrencilerin fen laboratuvar dersine, iş birliği içinde çalışmaya, webe dayalı öğrenmeye ve problem çözmeye yönelik olumlu tutuma sahip oldukları belirlenmiştir. Ayrıca, öğrencilerin yüz yüze öğrenme ortamlarını çevrimiçi ortamlara göre daha etkili olarak gördükleri ve çevrimiçi ortamlar ile ilgili teknik sorunlar yaşadıkları belirlenmiştir. Öğrencilerin açık uçlu sorulara verdikleri cevaplar incelendiğinde, öğrenciler pandemi dönemindeki uzaktan eğitim derslerinin tekrar izlenebilmesi ve zamandan tasarruf sağlaması yönlerinden olumlu bulurken; teknik ve internet kaynaklı sorunların olması, grup çalışmalarının etkisizliği, iletişim eksikliği ve eğitimdeki fırsat eşitsizliği yönlerinden olumsuzluk bulduklarını belirtmişlerdir.
\end{abstract}

Anahtar Kelimeler

Harmanlanmış öğrenme

Probleme dayalı öğrenme

Uzaktan eğitim Web tabanl öğrenme

\section{Abstract}

This study was carried out to determine the effectiveness of the problem-based blended learning environment prepared based on the characteristics of both face-to-face and e-learning environments and students' attitudes. The study group consists of 42 third grade students (28 females and 14 males) in the spring semester of the 2019-2020 academic year in a science teaching program at a state university. In the first half of the term, the students were given a face-to-face science teaching laboratory lesson as an experimental practice, with web-based problem-based science teaching laboratory lesson in the second half. At the end of the experimental applications, the data were obtained through the Web-Based Problem Based Learning Attitude Scale and the Blended Learning Environments Scale. In addition, the students' positive and negative opinions about the educational process during the pandemic period were collected from students through open-ended questions. As a result of the study, it was determined that the students had a positive attitude towards science laboratory lesson, collaborative working, web-based learning, and problem solving. In addition, it was determined that students perceive face-to-face learning environments as more effective than online environments and have technical problems with online environments. When the answers given by the students to the open-ended questions were examined, the students found it positive in terms of being able to watch the distance education lessons in the pandemic period again and save time. They stated that they experienced negativity in terms of technical and internet-based problems, ineffectiveness of group work, lack of communication and inequality of opportunity in education.

Keywords

Blended learning

Problem-based learning

Distance education

Web-based learning

$\begin{array}{lll}\text { Başvuru Tarihi/Received } & \text { Kabul Tarihi /Accepted } \\ 22.02 .2021 & 27.05 .2021 & \text { Araştırma Makalesi / Research Article | }\end{array}$

\section{Suggested APA Citation/Önerilen APA Atıf Biçimi:}

Hiğde, E., \& Aktamış, H. (2021). The investigation of the effectiveness of the problem-based blended learning environment and students' attitudes. Manisa Celal Bayar University Journal of the Faculty of Education, 9(1), 81-103. https://doi.org/10.52826/mcbuefd.884752.

${ }^{1}$ Sorumlu Yazar, Arş. Gör. Dr., Aydın Adnan Menderes Üniversitesi, Eğitim Fakültesi, Matematik ve Fen Bilimleri Eğitimi Bölümü, Fen Bilgisi Eğitimi, Aydın, TÜRKIYE; (i) https://orcid.org/0000-0002-4692-5119

2 Prof. Dr., Aydın Adnan Menderes Üniversitesi, Eğitim Fakültesi, Matematik ve Fen Bilimleri Eğitimi Bölümü, Aydın, TÜRKIYY; (iD) https://orcid.org/0000-0003-0717-5770 


\section{GİRIŞ}

Günümüzde 2019 Aralık ayından itibaren tüm dünyada yaşanan pandemi nedeniyle bireylerin bilgiye erişimi, kullanım alışkanlıkları, bilgi üretme ve yayma yolları değiştiği gibi, bireylerin çalışma ve öğrenme ortamları da değişmektedir. Çin' de ortaya çıkan daha sonra tüm dünyaya hızla yayılan ve ölümcül etkileri olan COVID-19 virüsü, bireylerin yaşamlarında önemli değişikliklere sebep olduğu gibi eğitim kurumlarında da önemli değişikliklere sebep olmuştur. Türkiye'de virüsün yayılmasını ve olumsuz etkilerini engellemek için örgün eğitim kurumlarının tamamının uzaktan eğitime zorunlu geçişine karar verilmiştir (MEB, 2020; YÖK, 2020). Uzaktan eğitim uzun yıllardır kullanılsa da pandemi dolayısı ile hızlı geçiş sebebiyle herhangi bir ön hazırlık yapılamamıştır. Hem öğretmen, hem öğrenci hem de diğer eğitim paydaşlarının herhangi bir ön hazırlığı olmadan uzaktan eğitime geçilmiştir. Öğrencilere ve öğretmenlere yönelik uzaktan eğitim ile ilgili bir eğitim veya bilgilendirme çalışması yapılamamıştır. Ayrıca pandeminin ani ortaya çıkışı sebebiyle uzaktan eğitimin gerektirdiği teknolojik okuryazarlık ve uzaktan eğitim ile ilgili herhangi bir program uygulanarak öğrencilerin yaşayabilecekleri problemlere yönelik ön çalışmalar zaman kısıtlığından dolayı gerçekleştirilememiştir. Bu nedenle, mevcut teknolojilerin eğitime entegrasyonu ile de eğitim ortamlarında farklılıklar ortaya çıkmaktadır (Can, 2020).

İnternetin ve web teknolojilerinin gelişmesi ile birlikte bu olanakların eğitim ortamlarına entegre edilmesi ile geleneksel öğretim ortamları dışında çevrimiçi eğitim ortamlarında da öğretim yapılabilmektedir. Yüz yüze öğretimin eksiklikleri çevrimiçi öğrenme ortamlarıyla bütünleştirilerek veya yüz yüze öğretimin mümkün olmadığ durumlarda sadece çevrimiçi öğretim ortamlarında öğretim yapılarak teknolojinin fırsatlarından yararlanılmaktadır. Yüz yüze ve çevrimiçi öğretimin birlikte kullanıldığı harmanlanmış öğretim ortamları kullanıcılara farklı fırsatlar sağlamaktadır. Harmanlanmış öğretim ortamları derslerin hem sınıf ortamında hem de sanal ortamda yürütülmesine olanak sağlamaktadır. Bu sayede öğrenciler ve öğretmenler hem yüz yüze hem de sanal ortamda iletişim kurarak dersleri daha aktif hale getirebilmektedir. Harmanlanmış öğretim ortamları öğrencilere farklı iletişim yolları sağlama, farklı ders materyallerine ulaşım, bireysel öğrenme ve öğretim süresince fırsat eşitliği sağlama gibi konularda avantaj sağlamaktadır (Anderson, 2004). Ek olarak, teknolojik açıdan zengin bir öğretim ortamı sağlayarak niteliği ve içeriği zenginleştirmektedir. Sadece yüz yüze veya çevrim içi ortamlarda öğretimin sınırlılıkları olmasına karşın harmanlanmış bir öğretim ortamında bu sınırlılıklar iki öğretim ortamının üstün yönlerinin birbirini tamamlamasıyla ortadan kalkmakta ve daha iyi bir öğretim ortamı oluşturulmaktadır. Ancak yüz yüze ve çevrimiçi öğretimin entegrasyonunda zaman ve teknolojinin nasıl kullanılacağına ilişkin tek ve kesin bir yöntem bulunmamaktadır. Yüz yüze ve çevrim içi ortamlarda işlenen konular, türleri ve kullanılan teknikler gibi birçok değişken uygulayıcı ve katılımcılara göre farklılık göstermektedir. Bu yüzden harmanlanmış öğretimin en iyi yönü yüz yüze ve çevrimiçi öğretimin güçlü olduğu yönlerini kullanarak öğrencilere etkili, interaktif ve esnek bir öğrenme fırsatı sağlamasıdır (Bozkurt, 2020).

Harmanlanmış öğretimin etkililiğinin ölçülmesi ve öğrenciler açısından değerlendirmesi harmanlanmış öğretimin kalitesini ve içeriğini geliştirmek için çok önemlidir. Bu nedenle, harmanlanmış öğretimin etkililiğinin değerlendirilmesinde alan yazında öğretmen, öğrenci, eğitim öğretim teknikleri, teknoloji ve iletişim gibi birçok boyut ve farklı değişken kullanılmıştır (Fresen, 2007). Yükseköğretim düzeyinde eğitmenlerin teknolojik yeterliliklerinin ve deneyimlerin yüksek olması, öğretim stil ve tutumlarının olması, eğitim ortamını ve eğitimin etkililiğini olumlu etkilemektedir (Selim, 2007). Özellikle daha önce çevrimiçi öğrenme ortamı deneyimleri ve çevrimiçi öğretime yönelik aldıkları eğitimler harmanlanmış öğretimin kalitesini arttırmaktadır (Sulčič ve Sulčič, 2007). Benzer şekilde öğrencilerinde teknoloji kullanımı, bireysel ve grupla iş birliği içinde çalışabilme ve zaman yönetimi gibi becerilerinin iyi düzeyde olması öğretimin etkililiğini etkileyen önemli etkenlerdir (Benigno ve Trentin, 2000). Bir diğer önemli faktör ise teknik altyapı ve destek hizmetleridir. Öğrenciler teknik destek alamadıklarında veya teknoloji ile ilgili sorun olduğunda motivasyonları ve eğitimin etkililiği düşmektedir (Soong, Chan, Chua ve Loh, 2001). Önemli faktörlerden biri de iletişim ve iş birliğidir. Hem öğrencilerin kendi aralarında hem de öğretmen ile iletişimlerinin iyi olması ve çevrimiçi olarak da bu iletişimin sağlanması eğitim ile ilgili birçok problemin 
üstesinden gelinmesinde ve öğrenciler arasında memnuniyetin artmasında etkilidir (Delialioglu ve Yıldırım, 2008; Gerber, Grund ve Grote, 2007; So ve Brush, 2008).

Harmanlanmış öğrenme ile ilgili alan yazındaki çalışmalar incelendiğinde uygulamalı derslerde harmanlanmış öğrenmenin pratik, işlevsel ve yenilikçi olarak görüldüğü (Yılmaz, 2017), bilgisayara, web tabanlı eğitime ve internete yönelik olumlu tutum geliştirdiği (Şimşek, 2009), bilimin doğası ve bilimsel araştırmayı anlamayı olumlu etkilediği (Kaya, 2014), güdülenmeyi sağladığı (Pesen, 2014), anlamlı ve kalıcı öğrenme ve öğretmen ile iletişimi sağladığı (Aydemir, 2012), fen laboratuvarı dersine yönelik olumlu tutum geliştirdiği ve istenilen hızda ve zamanda öğrenme esnekliği sunduğu (Kirişçioğlu, 2009) görülmektedir. Ayrıca, harmanlanmış öğrenme ortamı iş birliğine dayalı olması nedeni ile kaynak ve materyal ulaşımında fırsat eşitsizliğine sebep olabilmektedir (Means vd, 2013). Harmanlanmış öğrenmenin öğrenci memnuniyetini arttırdığl; esneklik, maliyet, kolay erişim, öğretmen ve öğrenciler arası etkileşim gibi konuların da harmanlanmış öğrenme ortamının kalitesini direkt etkileyerek öğrenci memnuniyeti ile ilişkili olduğu öne sürülmüştür (Ho vd., 2014). Harmanlanmış öğrenmenin geleneksel öğrenmeye göre olumlu tutum, akademik başarı, memnuniyet ve kendi kendine öğrenme üzerine anlamlı bir etkisi olduğu bulunmuştur (Akgündüz, 2013). Harmanlanmış öğrenmenin fen bilimleri öğretmen adaylarının teknolojik pedagojik alan bilgilerini geliştirmede yüz yüze işlenen özel öğretim derslerine göre daha etkili olduğu bulunmuştur (Sungur Alhan ve Şimşek, 2020). Yüz yüze ve harmanlanmış kimya laboratuvar derslerine katılan fen bilimleri öğretmen adaylarının harmanlanmış öğrenme ortamını pratik oluşu, bilgi paylaşımının hızlı olması, araştırmaya teşvik etmesi, derse hazırlıklı gelme, işbirlikli öğrenme sağlaması, yenilikçi ve farklı olmasından dolayı avantajlı gördükleri, yüz yüze öğrenme ortamını ise öğrenciye yönelik oluşu, internet ve bilgisayar kullanmadaki eksiklerinden dolayı tercih ettikleri görülmektedir (Yılmaz, 2017). Ortaokul öğrencileri ile gerçekleştirilen fen bilimleri dersinde uygulanan harmanlanmış öğrenme ortamının öğrencilerin akademik başarılarını ve fen eğitimine yönelik olumlu tutum geliştirmelerini sağladığı görülmüştür (Kadirhan ve Korkmaz, 2020).

Uzaktan eğitime geçilen bu dönemde ülkemizde öğretmen adaylarının görüşlerini belirlemeye yönelik birçok çalışma yapılmıştır. Fen, matematik, sınıf öğretmen adaylarıyla yapılan çalışmada öğretmen adaylarının genel olarak uzaktan eğitime uyum sorunu yaşadıkları, gelecek kariyerleri süresince uzaktan eğitimi kullanma niyetlerinin düşük olduğu görülmüştür (Karatepe, Küçükgençay ve Peker, 2020). Öğretmenlerin yaşadıkları sorunlar ve gerçekleştirdikleri uygulamaları incelendiğinde ise öğretmenlerin hem öğrenciler hem de aileleri ile iletişim sorunu yaşadıkları, öğrencilerini de okulun devam ettiğine inandırarak ve gelecek için umut verici ifadeler kullanarak motive etmeye çalıştıkları görülmüştür (Çakın ve Külekçi Akyavuz, 2020). Farklı bölgelerden fen bilimleri öğretmenleri ile yapılan bir çalı̧mada öğretmenlerin uzaktan eğitim sürecinde internet bağlantısı, öğrencilerle iletişim kurma, öğrencilerin derslere katılım oranının düşük olması ve okul yönetiminin baskısı gibi sorunlar yaşadıkları ve değişen ders materyalleri ile uygulamaya yönelik laboratuvar ve atölye derslerini tamamlayamama kaygılarının çok yükseldiği görülmüştür (Bakioğlu ve Çevik, 2020). Fen bilimleri dersinin uzaktan eğitim ile verilmesine yönelik 1000 ortaokul öğrencisi ile yapılan bir çalışmada öğrencilerin uzaktan eğitim sürecinde deney yapamadıkları, deney yapamadıkları için fen konularını kavramada zorluk yaşadıkları, motivasyonlarının azaldığı belirlenmiştir (Pınar ve Dönel Akgül, 2020).

Uygulamaya dayalı derslerde sadece çevrimiçi öğrenme veya harmanlanmış öğrenmenin yanında öğrencilerin aktif öğrenen olmasını sağlayan, onları tartışma ortamına sokan, hipotez kurma ve bağımsız araştırma yapmalarını sağlayan bir öğrenme sürecine ihtiyaç duyulmaktadır. Bu nedenle bu çalışmada probleme dayalı öğrenme (PDÖ) stratejisi uygulanması uygun görülmüştür. PDÖ, öğrencileri merkeze alarak onların aktif öğrenmelerini sağlar (Gürsul, 2008) ve öğrenilen bilgi ve becerilerin uygulamaya dönüştürülmesine yardımcı olur (Şendă̆, 2008). PDÖ bir problemden yola çıkarak öğrencilerin öğrenmelerini sağlarken aynı zamanda öğrencilerin arkadaşlarıyla daha fazla iş birliği yapmasına ve kaynakları daha etkin kullanmasına fırsat verir (Alper ve Deryakulu, 2008). Çevrimiçi ortamları, PDÖ etkinlikleri için gereken bilginin oluşturulması, saklanması, paylaşılması açısından daha hızlı ve olanakları fazla olan bir öğrenme ortamı sağlamaktadır. Bu nedenle 
harmanlanmış öğrenme ortamlarında PDÖ uygulanması öğrenen bireyler için çok sayıda öğrenme fırsatı sağlamaktadır.

Web ortamında yapılan derslerde, öğretmenler bilgi sağlayan öğretmen rolünden daha çok rehberlik eden öğretmen rolündedir (Tekedere, 2009). Bu sayede öğrencilerin sorumluluk duygularının geliştirilmesi sağlanır. Öğrenciler kendi bilgi ve anlamalarını yapılandırma şansı yakalayabilirler. Bu nedenle web tabanlı öğretim ortamı, PDÖ'nin öğrenciyi merkeze alarak bilgiyi aktif olarak kendi yapılandırmasını önemli ölçüde desteklemektedir. Web ortamında öğrenci öğretmen arasındaki iletişim ve iş birliği sağlanması öğrencilerin öğrenmek için tartışma ortamına girmesine, iş birliği yaparak problemi çözmesine önemli katkısı olmaktadır (An, 2006). Sınıf içinde etkileşimli ortamın sağlandığı gibi web ortamında da forumlar, çevrimiçi gruplar ve uzaktan eğitim portalları gibi olanaklar, PDÖ grupları için tartışma ortamının kurulması, öğrenciler ve öğretmen arasında bilginin paylaşılabilmesi için olanak sağlamaktadır. Sınıf içinde yüz yüze eğitimin olmadığı koşullarda PDÖ için gerekli olan zengin kaynaklara kolay erişim ve öğrencilerin arkadaşları, uzmanlar ve öğretmenleri ile fikir alışverişi sağlayabilmeleri için web tabanlı öğrenme olanakları kullanılabilir. Bu sayede öğrenciler web aracılığıyla bir problemi araştırabilir, bilgiye kolay erişim sağlayabilir, çözüme rahatça ulaşabilir ve kendi bilgilerini yapılandırma fırsatı yakalayabilirler (Günbatar, 2009).

Web tabanlı PDÖ'nin öğrenci tutumlarına yönelik yapılan bir çalışmada öğrencilerin bu öğretim yöntemini etkileşimli, problem çözme becerisini geliştirici, işbirlikçi öğrenme ortamı sağlayıcı, yararlı ve etkili gördükleri öğrenci görüşmelerinden ortaya çıarılmıştır (Tseng, Chang ve Lou, 2012). Başka bir çalışmada ilk kez web tabanlı PDÖ ortamında derse katılan öğrenciler ise çevrimiçi öğrenmeye yatkın olmadıkları için düşük seviyede bir tutuma sahip oldukları, ancak PDÖ’nin sağladığı etkileşimli ortama yönelik yüksek düzeyde olumlu tutuma sahip oldukları bulunmuştur (Tseng, Chiang ve Hsu; 2008). Web tabanlı PDÖ çalışmalarında öğrencilerin öğrenmeye ve PDÖ uygulamasına yönelik tutum geliştirdikleri, problem tabanlı teoriye göre tüm derslerin içeriğinin hazırlanmasını ve gerçek yaşam problemleri içermesini istedikleri sonucuna ulaşılmıştır (Tsai ve Tang, 2017).

Bu çalışmada son zamanlarda yaşanan pandeminin etkisiyle dünya üzerinde neredeyse tüm ülkelerde olduğu gibi ülkemizde de uzaktan eğitime hızlı ve plansız bir geçiş yapılmıştır. Ancak bu hızlı geçiş döneminde eğitimin hem öğrenciler hem de diğer paydaşlar açısından nasıl etkilendiğine yönelik az sayıda araştırma vardır. Bu çalışmada da pandeminin ülkemizde ilk Covid 19 vakasının görülmesiyle ve yükseköğretim kurumlarında uzaktan eğitime geçilmesiyle birlikte harmanlanmış bir eğitim modeli uygulanmıştır. Bu harmanlanmış eğitim ortamı hem yüz yüze ve hem de uzaktan eğitimin sağladığı fırsatlardan yararlanmaya imkân verdiği için tercih edilmiştir. İçinde bulunduğumuz bu olağanüstü süreç göz önünde bulundurulduğunda ister istemez uzaktan eğitim uygulamasına geçilmiştir. Ancak tüm dünyayı etkisi altına alan bu süreç sona erdiğinde uygulanan eğitim programları da dâhil hiçbir şey eskisi gibi olmayacaktır. Bu durumun eğitime yansımalarından biri de kuşkusuz eğitimin yüz yüze olmasının yanında uzaktan eğitime de yer verileceğidir. Nitekim Yükseköğretim Kurulu da lisans programlarındaki derslerin \%30'nun uzaktan eğitim şeklinde verilebileceği yönünde bir karar almış daha sonra Mili eğitim bakanlığı ile birlikte tamamen uzaktan eğitime geçilmiştir (MEB, 2020; YÖK, 2020). Bu bağlamda yapılan çalışma ile pandemiden sonraki süreçte de eğitim uygulamalarımıza entegre edeceğimiz uzaktan eğitimi nasıl entegre edebileceğimize bir örnek oluşturması açısından da alana katkı sağlayacağı düşünülmektedir. Ayrıca alan yazın incelendiğinde fen eğitiminde fen laboratuvarı gibi uygulamalı bir ders kapsamında probleme dayalı olarak hem yüz yüze hem de uzaktan eğitim ile yürütülmesi ve etkililiğine yönelik öğrenci tutumlarını ve uzaktan eğitime yönelik öğrenci görüşlerini inceleyen bir araştırma ile karşılaşılmamıştır. Bu nedenle bu çalışmanın amacı probleme dayalı fen laboratuvar dersinin harmanlanmış öğrenme ile uygulanması sonucunda fen bilgisi öğretmenliği öğrencilerinin harmanlanmış öğrenme ortamını ne düzeyde etkili gördükleri, öğrencilerin web tabanlı probleme dayalı öğrenmeye yönelik tutumları üzerindeki etkisi ve öğrencilerin uzaktan eğitime yönelik görüşlerinin neler olduğu belirlenmeye çalışılmıştır.

1. Probleme dayalı harmanlanmış öğrenmenin öğrencilerin web tabanlı problem çözmeye yönelik tutumları üzerindeki etkisi nedir? 
2. Probleme dayalı harmanlanmış öğrenmenin öğrencilerin harmanlanmış öğrenme ortamı etkililiğine yönelik puanları üzerindeki etkisi nedir?

3. Probleme dayalı harmanlanmış öğrenme ortamındaki öğrencilerin uzaktan eğitime yönelik olumlu ve olumsuz görüşleri nelerdir?

\section{YÖNTEM}

$\mathrm{Bu}$ araştırmada deneysel desenlerden olan tek grup son test deneysel model kullanılmıştır. Çalışmada öğrencilere öğrenme stratejisi olarak harmanlanmıs, öğrenme ortamı olarak Web tabanlı probleme dayalı öğrenme ve yüz yüze probleme dayalı öğrenme uygulanmıştır. Bu araştırmada hem nicel veriler (Web Tabanlı Probleme Dayalı Öğrenme Tutum Ölçeği ve Harmanlanmış Öğrenme Ortamları Ölçeği ile) hem de nitel veriler (Uzaktan Eğitime Yönelik Açık Uçlu Sorular ile) toplanarak araştırma sorusuna cevap aranmaya çalışılmıştır. Bu modelde, oluşturulan bir gruba bağımsız değişken uygulanmakta ve bağımlı değişken üzerindeki etkisi gözlenmektedir (Karasar, 2013). Bu probleme dayalı harmanlanmış öğrenme uygulaması sonucunda öğrencilerin web tabanlı probleme dayalı öğrenmeye yönelik tutumları, harmanlanmış öğrenmenin etkililiği ve uzaktan öğretime yönelik görüşleri araştırılmıştır.

\section{Çalışma Grubu}

Bu çalışmanın katılımcı grubunu Ege Bölgesindeki bir devlet üniversitesinde Eğitim Fakültesi Fen Bilgisi Öğretmenliği Anabilim Dalında eğitim alan Fen Öğretimi Laboratuvar Uygulamaları II dersine katılan 42 üçüncü sınıf öğrencisi oluşturmaktadır. Katılımcıların 28'i kadın, 14'ü erkek bireydir. Örneklem seçiminde, amaçlı örnekleme yöntemi kullanılmıştır (Gürbüz ve Şahin, 2014). Fen Öğretimi Laboratuvar Uygulamaları II dersinin seçilmesi çalışma grubunun kolay ulaşılabilir olması, grup çalışmasına uygun olması ve uygulama temelli bir ders olmasından dolayıdır. Derse katılan tüm öğrenciler gönüllü olarak çalışmaya katılmışlardır.

\section{Ölçme Aracı}

\section{Web Tabanlı Probleme Dayalı Öğrenme Tutum Ölçeği (WTPDÖ)}

$\mathrm{Bu}$ ölçme aracı web tabanlı gerçekleştirilen probleme dayalı öğrenme süreci sonunda öğrenci tutumlarını belirlemek amacıyla Alper (2003) tarafından geliştirilmiştir. Ölçme aracı toplam 39 maddeden ve beş alt faktörden oluşmaktadır. Ölçeği yanıtlayan öğrenciler "Kesinlikle katılıyorum" (5) ile "Kesinlikle katılmıyorum" (1) arasında değişen beşli derecelendirme kullanmışlardır. Ölçekten alınabilecek en yüksek puan 195; en düşük puan ise 39'dur. Ölçeğin geçerlik ve güvenirliğinin belirlenmesi için fen bilgisi öğretmenliği okuyan lisans öğrencilerine uygulanmıştır. Yapı geçerliliği için faktör analizi, güvenirlik için Cronbach alfa katsayısı hesaplanmıştır. Toplam 39 maddeden oluşan ölçek faktör analizi sonucunda beş alt faktörden oluştuğu bulunmuştur. Ölçeğin faktör analizi sonucunda 39 maddenin ve beş alt faktörünün açıkladığı varyansın sırasıyla \%16.32, \%13.65, \%11.59, \%11.20 ve \%9.72 olduğu görülürken, ölçeğin açıkladığı toplam varyansının \%62.49 olduğu görülmektedir. Ölçeğin son halinde bulunan beş alt faktörün yüklerinin sırasıyla .327 ile 778; .452 ile .810; .516 ile .775; .529 ile .813; .366 ile 685 arasında değiştiği görülmüsstür. Ölçeğin alt faktörleri sırasıyla "Fen laboratuvar dersine ilişkin maddeler”, "İşbirliğine dayalı öğrenme”, “Web’e dayalı öğrenme”, “Kendi kendine öğrenme” ve “Problem çözme” olarak tanımlanmıştır. Ölçeğin tamamına ait Cronbach Alpha güvenirlik katsayısı .92, alt faktörlere ait güvenirlik katsayısı sırasıyla .76, .90, .79, .83 ve .77 değerleri bulunmuştur. Ölçeğin faktörleri ve güvenirlik katsayıları orijinal ölçek ile paralellik göstermektedir.

\section{Harmanlanmış Öğrenme Ortamları Ölçeği}

$\mathrm{Bu}$ ölçme aracı hem yüz yüze hem de çevrimiçi öğrenme ortamlarının özelliklerinden yola çıkarak harmanlanmış öğrenme ortamlarının ne derece etkili olduğunu belirlemeye yönelik Cabı ve Gülbahar (2013) tarafından geliştirilmiştir. Ölçme aracı toplam 55 maddeden ve dört faktörden oluşmaktadır. Beşli likert tipi ölçek "hiçbir zaman”, "nadiren”, "ara sıra", "sık sık" ve "her zaman” seçeneklerinden oluşmaktadır. Ölçekten alınabilecek maksimum puan 275; minimum puan ise 55'tir. Ölçeğin geçerlik ve güvenirliğinin belirlenmesi için fen bilgisi 
öğretmenliği ana bilim dalında okuyan lisans öğrencilerine uygulanmıştır. Yapı geçerliliği için faktör analizi, güvenirlik için Cronbach alfa katsayısı hesaplanmıştır. Toplam 55 maddeden oluşan ölçek faktör analizi sonucunda dört alt faktörden oluştuğu bulunmuştur. Ölçeğin faktör analizi sonucunda 55 maddenin ve dört alt faktörün açıkladığı varyansın sırasıyla \%22.82, \%14.60, \%11.91 ve \%10.64 olduğu görülürken, ölçeğin açıkladığı toplam varyansının \%59.96 olduğu görülmektedir. Ölçeğin son halinde bulunan dört alt faktörün yüklerinin sırasıyla .333 ile .874; .319 ile .822; .434 ile .880; .320 ile .448 arasında değiştiği görülmüştür. Ölçeğin faktörleri sırasıyla "Yüz Yüze Öğrenme Ortamları" "Çevrimiçi Öğrenme Ortamları", "Harmanlanmış Öğrenme Ortamları", “Teknik Boyutlar” faktörleridir. Ölçeğin tamamına ait Cronbach Alpha güvenirlik değeri .91 bulunurken, alt faktörler için sırasıyla .89, $.92, .95$ ve .89 değerleri bulunmuştur. Ölçeğin faktörleri ve güvenirlik katsayıları orijinal ölçek ile paralellik göstermektedir.

\section{Uzaktan Eğitime Yönelik Açık Uçlu Sorular}

Çalışmada araştırmacı tarafından hazırlanan açık uçlu sorular yardımıyla öğrencilerin uzaktan eğitime ilişkin olumlu ve olumsuz görüşlerini belirlenmeye çalışılmıştır. Açık uçlu sorularda uzaktan eğitime ilişkin öğrencilerin yaşadıkları olumlu ve olumsuz görüşlerini maddeler halinde sıralamaları ve en az üç olumlu üçte olumsuz görüş yazmaları beklenmektedir. Sorulan sorular aşă̆ıda verilmiştir.

1. Uzaktan eğitimin olumlu bulduğunuz yönleri nelerdir? Lütfen kısaca ve maddeler halinde yazınız.

2. Uzaktan eğitimin olumsuz bulduğunuz yönleri nelerdir? Lütfen kısaca ve maddeler halinde yazınız.

\section{Harmanlanmış Öğrenme Uygulaması}

Uygulamada ilk yedi hafta öğrencilerle yüz yüze olarak eğitimler gerçekleştirilmiştir. Yüz yüze eğitimlerde öğrencilere Fen laboratuvarı ile ilgili teorik bilgiler verilirken uygulamalı kısımlarda laboratuvar ortamında öğrenciler deneyler yapmışlardır. Laboratuvarda yapılan deneylerde öğrenciler beşer kişilik gruplara ayrılarak her hafta bir fen konusu ile ilgili senaryo verilmiştir.

\section{Örnek Senaryo}

Ayşe'nin ablası üniversitede okumaktadır. Tatilde eve geldiğinde Ayşe ve ablasına annesi bodrum katındaki depoyu temizlemelerini ve kendilerine ait eşyalardan ihtiyacı olmayanları ayırmalarını ister. Ayşe ve ablası depoyu temizlerken Ayşe'nin ablasının ilkokuldan kalma anılarını sakladığı kutuyu görür. Ayşe kutuyu merak eder ve ablasına içine bakmak istediğini söyler. Ablası ile birlikte kutuyu açarlar. Kutunun içinde çıartmalar, kilitli bir hatıra defteri, gümüş bir yüzük, birkaç tane bozuk para ve bir anahtar vardır. Anahtar hatıra defterinin anahtarıdır. Açmak için anahtarı alırlar ancak anahtarın renginin değiştiğini ve kütle miktarının arttığını görürler. Ayrıca bozuk paraların farklı renkler aldığını ve gümüş yüzügü̈n de karardığını görürler. Bu değişimlerin nedenlerini açıllamada ve tekrar eski haline getirmede onlara yardımcı olur musunuz?

Öğrenciler verilen senaryolarla ilgili bir sonraki haftaya kadar deneylerini tasarlayarak laboratuvara gelmişlerdir. Laboratuvarda grupça verilen senaryoya yönelik tasarladıkları deneyleri yapmışlardır. Dersin öğretim üyesi ve bir araştırmacı deneyler sırasında öğrencilerle bilimsel tartışmalarda bulunarak deneylerle ilgili geri dönüt almışlardır. Öğrenciler deneyleri tasarlarken bilimsel süreç becerilerine uygun olarak tasarımlar yapmışlardır.

Uygulamanın uzaktan eğitim kısmında ise yine öğrencilere senaryolar verilmiştir. Ancak bu uygulamalarda öğrenciler grup halinde değil, bireysel olarak senaryolara yönelik problem durumlarını belirlemiş, bilimsel süreç basamaklarına uygun olarak deneylerini tasarlamış ve yapmışlardır. Her öğrenci bireysel olarak yaptığı deneyi videoya çekerek uzaktan eğitim sırasında çevrimiçi olarak derste sınıf arkadaşları ile deneylerini paylaşmışlardır. Tüm deneyler incelenerek sınıftaki diğer öğrencilerle birlikte değerlendirilmiş ve geri bildirimler alınmıştır. Bu uygulamalar sırasında öğrenciler bireysel olarak deneyleri yaptıkları için her öğrenci elinde bulunan imkânlara göre yaratıcılıklarını da kullanarak farklı şekillerde deneyleri tasarlamışlardır. 
Veri Analizi

Nicel verilerin analizi için ölçeklerdeki maddelerin aritmetik ortalamaları, standart sapmaları, Cronbach Alpha, korelasyon analizi yapılmıştır. Nitel verileri için ise öğrencilerden açık uçlu sorular yardımıyla toplanan yazılı cevaplar analize başlanmadan önce veri birimleri ayrıntılı olarak incelenmiş, ilişkili olan kavramlar daha önceden belirlenmiş olan olumlu ve olumsuz kategoriler altında gruplandırılmıştır. Betimsel analizde veriler araştırma sorularının ortaya koyduğu boyutlar ya da sorular olarak düzenlenebilir veya görüşme ve gözlemlerde kullanılan sorular ve alt boyutlar kullanılarak belirlenebilmektedir (Yıldırım ve Şimşek, 2013). Bu sebeple öğrencilere sorulan olumlu ve olumsuz yönler temalar olarak kullanılmıştır. Verilerin çözümlenmesinde öğrencilerin cevapları excel dosyasında kaydedilmiştir. Bu dosyadaki metinler daha önceden belirlenen temalar temelinde sözcükler ve anlamlı yapılar biçiminde kodlanmıştır. Öğrencilere ait yanıtlardan doğrudan alıntılar hiçbir değişiklik yapılmadan ilgili tablolarda verilmiştir. Betimsel analizde amaç, elde edilen bulguları sistematik şekilde ve yorumlanmış bir şekilde okuyucuya sunmaktır (Yıldırım ve Şimşek, 2013). Öğrencilerden elde edilen bulgular, sistematik ve açı bir biçimde betimlenmiş ve alan yazına dayanarak yorumlanmıştır. Çalışma verileri sunulurken öğrencilerin isimleri yerine rumuz harfler kullanılmıştır.

\section{Araştırmanın Etik İzinleri}

Etik değerlendirmeyi yapan kurul adı: Aydın Adnan Menderes Üniversitesi Rektörlüğü Eğitim Araştırmaları Etik Kurulu

Etik değerlendirme kararının tarihi: 09.07.2020

Etik değerlendirme belgesi sayı numarası: 36161

\section{BULGULAR}

Öğrencilerin yapılan uygulama sonucunda WTPDÖ tutum ölçeği ve harmanlanmış öğrenme ortamları ölçeğinden aldıkları puanlara ait ortalama, standart sapma ve madde bazında yüzde değerleri Tablo 1, 2, 3 ve 4 'te verilmiştir.

Aşağıda Tablo 1'de WTPDÖ tutum ölçeğinin alt faktörlerinden alınan puanların cinsiyete göre ortalama ve standart sapma değerleri verilmiştir. Bu değerlere göre kadın ve erkek öğrencilerin tüm ölçeğe ait ortalama puanlarının birbirine yakın olduğu ve orta değer olan 3.5 değerinin üzerinde olduğu görülmektedir. Alt faktörlere ait ortalama değerlere bakıldığında fen laboratuvarına ilişkin tutum ( $\mathrm{M}=4.34)$, iş birliğine dayalı öğrenme $(\mathrm{M}=4.46)$, webe dayalı öğrenme ( $M=4.15)$, kendi kendine öğrenme ( $M=3.67)$ ve problem çözme $(M=4.53)$ değerlerinin ortalama değer olan 3.5 değerinin üzerinde olduğu ve kadın ve erkek öğrencilerin tutum puanlarının yakın olduğu görülmektedir.

Tablo 1. WTPDÖ Tutum Ölçeğinin Ortalama ve Standart Sapma Değerleri

\begin{tabular}{ccccccccccccc}
\hline & \multicolumn{2}{c}{$\begin{array}{c}\text { Fen } \\
\text { Laboratuvar }\end{array}$} & \multicolumn{2}{c}{$\begin{array}{c}\text { İsbirliğine } \\
\text { Dayalı } \\
\text { Öğrenme }\end{array}$} & $\begin{array}{c}\text { Web'e Dayalı } \\
\text { Öğrenme }\end{array}$ & $\begin{array}{c}\text { Kendi Kendine } \\
\text { Öğrenme }\end{array}$ & Problem Çözme & Toplam \\
\hline Cinsiyet & $\mathrm{M}$ & $\mathrm{SD}$ & $\mathrm{M}$ & $\mathrm{SD}$ & $\mathrm{M}$ & $\mathrm{SD}$ & $\mathrm{M}$ & $\mathrm{SD}$ & $\mathrm{M}$ & $\mathrm{SD}$ & $\mathrm{M}$ & SD \\
\hline Kadın & 4.32 & .43 & 4.48 & .56 & 4.28 & .44 & 3.61 & .46 & 4.49 & .47 & 4.24 & .33 \\
Erkek & 4.39 & .39 & 4.41 & .59 & 3.90 & .77 & 3.78 & .51 & 4.60 & .44 & 4.21 & .38 \\
Toplam & 4.34 & .42 & 4.46 & .56 & 4.15 & .59 & 3.67 & .48 & 4.53 & .46 & 4.23 & .35 \\
\hline
\end{tabular}

Öğrencilerin fen laboratuvarına ilişkin maddelere verdikleri cevaplar incelendiğinde öğrencilerin çoğunluğunun kesinlikle fen laboratuvarında öğrendikleri bilgilerin günlük yaşam için yararlı olduğunu (\%76.2), öğrendiklerini gelecekte kullanabileceklerini (\%69), yeni öğrendiklerinin önceki bilgilerini desteklediğini (\%69), fen laboratuvar dersini problem çözümü için araştırmaktan zevk aldıklarını (\%64.3) ve güncel sorunlar hakkında fen laboratuvarında öğrendiklerini uzun süre hatırladıklarını (\%78.6) belirtmektedir. Ancak öğrencilerin neredeyse üçte 
ikisinin web ortamında fen laboratuvarı çalışmanın onları güdülemesi (\%31) ve fen laboratuvarında öğrendiklerinin ilginç olması (\%33.3) hakkında kararsız oldukları görülmektedir (Tablo 2).

İşbirliğine yönelik maddelere verilen cevaplara göre öğrencilerin grup çalışmasını tercih etme (\%69), sorumluluk alma (\%71.4), problem çözmek için grupla çalışma (\%66.7) ve gerçek yaşamla ilgili konulardan motive olma (78.6) gibi tüm maddelere çoğunluğun kesinlikle katıldığı belirlenmiştir (Tablo 2).

Webe dayalı öğrenmeye yönelik öğrencilerin çoğunluğunun sınıf dışında arkadaşlarıyla web iletişim araçlarıyla iletişim kurabileceğini (\%83.3), web araçlarıyla iletişim kurmak isteyeceğini (\%66.7), çevrimiçi sınav sonuçlarını hemen öğrenmeyi tercih ettiğini (\%73.8) ve web arama motorlarından bilgi edinebildiğini (\%71.4) ifade ettikleri görülmektedir. Ancak öğrencilerin çoğunluğunun web ortamında sınav olmayı tercih etmediği belirlenmiştir (\%59.5).

Kendi kendine öğrenmeye yönelik öğrencilerin çoğunluğunun yeni konuları kendi gayretiyle öğrenebileceğini (\%50) ve öğrenmek için sorumluluk alabileceğini (\%66.7) ifade ettikleri görülmüştür. Ancak hala öğrencilerin dörtte bire yakını hedeflere tek başına ulaşmada (\%23.8), öğretmen yardımı olmadan ders notlarıyla çalışarak öğrenebilmede (\%21.4) ve zor problemleri çözebilmede (\%26.2) kararsız kaldıkları ifade etmektedir.

Problem çözmeye yönelik öğrencilerin çoğunluğunun problem çözerek öğrenmek istediği (\%66.7), verilen konu ile ilgili bilgi toplayabildiği (\%61.9), güncel problemlerle öğrenmek istediği (\%71.4), web ortamı yerine sınıf içi yüz yüze iletişimi tercih ettiği (\%76.2) ve ön bilgilerini kullanabileceklerini (\%81) belirtmişlerdir. Ancak öğrencilerin dörtte biri problem çözmek için birileriyle yarışmaktan hoşlanma konusunda kararsız olduklarını ifade etmektedir (\%23.8).

Tablo 2. WTPDÖ Tutum Ölçeğinin Maddelerine İlişkin Yüzde Değerleri

\begin{tabular}{|c|c|c|c|c|c|c|c|}
\hline Maddeler & -- & - & 0 & + & ++ & $\mathrm{M}$ & $\mathrm{SD}$ \\
\hline Fen lab dersinde verilen bilgiler günlük yaşam için yararlıydı. & 0 & 0 & 2.4 & 21.4 & 76.2 & 4.74 & .50 \\
\hline $\begin{array}{l}\text { Fen lab dersinde öğrendiğim bilgilerin çoğu gelecekte kullanılabilecek } \\
\text { türdendi. }\end{array}$ & 0 & 2.4 & 0 & 28.6 & 69 & 4.64 & .62 \\
\hline Fen lab dersinde öğrendiklerim önceden bildiklerimi destekledi. & 0 & 0 & 2.4 & 28.6 & 69 & 4.67 & .53 \\
\hline Fen lab dersinde yeni bilgiler edindim. & 0 & 0 & 21.4 & 33.3 & 45.2 & 4.24 & .79 \\
\hline Web ortamında Fen lab dersi çalışmak beni güdüler. & 7.1 & 16.7 & 31 & 19 & 26.2 & 3.40 & 1.25 \\
\hline Fen lab dersinde öğrendiklerim benim için ilginçti. & 0 & 9.5 & 33.3 & 33.3 & 23.8 & 3.71 & .94 \\
\hline $\begin{array}{l}\text { Problemlerin çözümünü araştırarak Fen lab dersi konularını çalışmaktan zevk } \\
\text { alırım. }\end{array}$ & 0 & 0 & 4.8 & 31 & 64.3 & 4.60 & .59 \\
\hline $\begin{array}{l}\text { Güncel bir sorunu araştırarak öğrendiğim Fen lab dersi konularını uzun süre } \\
\text { hatırlarım. }\end{array}$ & 0 & 2.4 & 0 & 19 & 78.6 & 4.74 & .59 \\
\hline Herkesin eşit katılım sağladığı grup çalışmalarını tercih ederim. & 0 & 2.4 & 19 & 9.5 & 69 & 4.45 & .89 \\
\hline Grup çalışmasının zaman kaybı olduğunu düşünmüyorum. & 0 & 11.9 & 19 & 16.7 & 52.4 & 4.10 & 1.10 \\
\hline Grup çalışmalarında çeşitli sorumluluklar almak isterim. & 0 & 0 & 2.4 & 26.2 & 71.4 & 4.69 & .52 \\
\hline Çeşitli çözümleri olan bir problemi çözmek için grupla çalışm & 0 & 0 & 9.5 & 23.8 & 66.7 & 4.57 & .67 \\
\hline Grup çalışmasında çeşitli sorumluluklar almak beni güdüler (motive eder). & 0 & 0 & 4.8 & 33.3 & 61.9 & 4.57 & .59 \\
\hline Grup içinde ortak çalışmaktan hoşlanırım. & 0 & 0 & 14.3 & 38.1 & 47.6 & 4.33 & .72 \\
\hline Problemi çözmek için grupla birlikte çalışmak isterim. & 0 & 0 & 16.7 & 31 & 52.4 & 4.36 & .76 \\
\hline Grupta arkadaşlarımla çalışmaktan memnunum. & 4.8 & 2.4 & 14.3 & 19 & 59.5 & 4.26 & 1.10 \\
\hline Gerçek yaşamla ilgili konuları çalışmak beni güdüler (motive eder). & 0 & 0 & 4.8 & 16.7 & 78.6 & 4.74 & .54 \\
\hline $\begin{array}{l}\text { Grup içinde daha önceden konuyla ilgili bilgi sahibi olan öğrenci arkadaşlarla } \\
\text { problemi çözmek isterim. }\end{array}$ & 0 & 0 & 14.3 & 21.4 & 64.3 & 4.50 & .74 \\
\hline $\begin{array}{l}\text { Sınıf dışında grup arkadaşlarımla web ortamındaki iletişim araçlarıyla (e-mail, } \\
\text { Chat, discussion gibi) iletişim kurabilirim. }\end{array}$ & 0 & 0 & 2.4 & 14.3 & 83.3 & 4.81 & .45 \\
\hline $\begin{array}{l}\text { Web ortamındaki araçlarla (e-mail, Chat, discussion gibi) gerek sınıf içinde } \\
\text { gerek sınıf dışında arkadaşlarımla görüşmeyi isterim. }\end{array}$ & 0 & 0 & 19 & 14.3 & 66.7 & 4.48 & .80 \\
\hline $\begin{array}{l}\text { Web ortamında çevrimiçi yapılan sınavların sonuçlarını anında öğrenmeyi } \\
\text { tercih ederim. }\end{array}$ & 0 & 0 & 16.7 & 9.5 & 73.8 & 4.57 & .77 \\
\hline Fen lab dersindeki sorunları web ortamında araştırarak çözmek isterim. & 4.8 & 0 & 26.2 & 33.3 & 35.7 & 3.95 & 1.03 \\
\hline $\begin{array}{l}\text { Öğretmenimin e-mail gibi iletişim araçlarıyla web ortamında anında geri } \\
\text { bildirim (dönüt-feed back) vermesi beni güdüler (motive eder). }\end{array}$ & 0 & 7.1 & 7.1 & 16.7 & 69 & 4.48 & .92 \\
\hline
\end{tabular}


Web ortamında arkadaşlarımla iletişim kurmaktan zevk alırım.

Web ortamında arama motorlarından bilgi edinebilirim.

Web ortaminda sinav olmayı isterim.

Hedeflere tek başıma ulaşabilirim.

Yeni verilen bir konuyu kendi gayretimle öğrenebilirim.

Öğretmenin yardımı olmadan çeşitli öğretim materyallerini ve ders notlarını

çalışarak öğrenebilirim.

Zor problemleri çözebilirim.

Güç bir problemle karşılaştığımda çeşitli çözümler bulurum.

Karmaşık bir problemi çözmek için çaba göstermekten zevk alırım.

Öğrenmek için gereken sorumluluğu alabilirim.

Fen lab dersini problem-sorun çözerek öğrenmek isterim.

Verilen konu ile ilgili bilgileri toplayabilirim.

Fen lab dersini güncel problemlerle öğrenmek isterim.

Web ortamındaki öğretim yerine sınıf içinde yüz yüze iletişimi tercih ederim.

Problemi çözmek için başkalarıyla yarışmaktan hoşlanırım.

Problemi çözmeme yardımcı olabilecek ön bilgilerimi kullanırım.

\begin{tabular}{ccccccc}
7.1 & 4.8 & 19 & 23.8 & 45.2 & 3.95 & 1.23 \\
0 & 0 & 4.8 & 23.8 & 71.4 & 4.67 & .57 \\
33.3 & 26.2 & 26.2 & 2.4 & 11.9 & 2.33 & 1.30 \\
\hline 2.4 & 0 & 23.8 & 45.2 & 28.6 & 3.98 & .87 \\
0 & 2.4 & 14.3 & 33.3 & 50 & 4.31 & .81 \\
0 & 4.8 & 21.4 & 50 & 23.8 & 3.93 & .81 \\
& & & & & & \\
0 & 2.4 & 26.2 & 47.6 & 23.8 & 3.93 & .78 \\
0 & 2.4 & 7.1 & 50 & 40.5 & 4.29 & .71 \\
0 & 0 & 14.3 & 40.5 & 45.2 & 4.31 & .72 \\
0 & 2.4 & 2.4 & 28.6 & 66.7 & 4.60 & .66 \\
\hline 0 & 2.4 & 2.4 & 28.6 & 66.7 & 4.60 & .66 \\
0 & 0 & 4.8 & 33.3 & 61.9 & 4.57 & .59 \\
0 & 0 & 2.4 & 26.2 & 71.4 & 4.69 & .52 \\
0 & 2.4 & 7.1 & 14.3 & 76.2 & 4.64 & .73 \\
9.5 & 2.4 & 23.8 & 19 & 45.2 & 3.88 & 1.29 \\
0 & 0 & 2.4 & 16.7 & 81 & 4.79 & .47 \\
\hline
\end{tabular}

(++=kesinlikle katılıyorum, +=katıllyorum, 0=kararsızım, -=katılmıyorum, --=kesinlikle katılmıyorum)

Aşağıda Tablo 3'te harmanlanmış öğrenme ortamları ölçeğinin alt faktörlerinden alınan puanların cinsiyete göre ortalama ve standart sapma değerleri verilmiştir. Bu değerlere göre kadın ve erkek öğrencilerin tüm ölçeğe ait ortalama puanlarının birbirine yakın olduğu ve orta değer olan 3.5 değerinin az üzerinde olduğu görülmektedir. Alt faktörlere ait ortalama değerlere bakıldığında yüz yüze öğrenme ortamları $(M=4.46)$, çevrimiçi öğrenme ortamları

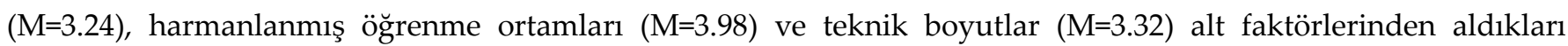
ortalama değerlerin ortalama değer olan 3.5 değerinin üzerinde veya az altında olduğu ve kadınların teknik alt faktör hariç tüm alt faktörlerde daha yüksek ortalama değere sahip olduğu görülmektedir.

Tablo 3. Harmanlanmış Öğrenme Ortamları Ölçeğine Ait Ortalama ve Standart Sapma Değerleri

\begin{tabular}{ccccccccccc}
\hline & \multicolumn{2}{c}{$\begin{array}{c}\text { Yüz Yüze Öğrenme } \\
\text { Ortamları }\end{array}$} & \multicolumn{2}{c}{$\begin{array}{c}\text { Çevrimiçi Öğrenme } \\
\text { Ortamları }\end{array}$} & \multicolumn{2}{c}{$\begin{array}{c}\text { Harmanlanmış } \\
\text { Öğrenme Ortamları }\end{array}$} & \multicolumn{2}{c}{ Teknik Boyutlar } & Toplam \\
\hline Cinsiyet & M & SD & M & SD & M & SD & M & SD & M & SD \\
\hline Kadın & 4.50 & .56 & 3.35 & .77 & 4.10 & .78 & 3.14 & 1.14 & 3.77 & .37 \\
Erkek & 4.39 & .48 & 3.02 & .60 & 3.75 & .43 & 3.69 & .92 & 3.71 & .24 \\
Toplam & 4.46 & .54 & 3.24 & .73 & 3.98 & .70 & 3.32 & 1.09 & 3.75 & .33 \\
\hline
\end{tabular}

Öğrencilerin harmanlanmış öğrenme ortamları ölçeğine verdikleri cevaplar incelendiğinde öğrencilerin yarısından çoğunun yüz yüze öğrenme ortamlarını çevrimiçi ortamlara göre her zaman daha etkili bulduğu görülmektedir. Çevrimiçi öğrenme ortamlarına yönelik öğrencilerin verdikleri cevaplar incelendiğinde sadece üçte birine yakını çevrimiçi ortamlarda her zaman daha çok sorumluluk duygusu hissettiğini (\%31) ve ders çalışırken sorularına iletişim araçları kullanarak yanıt aramaya çalıştığını (\%33.3) ifade etmektedir. Bazı öğrencilerin ise sık sık çevrimiçi ortamlarda ders çalışırken sorularına iletişim araçları kullanarak yanıt aramaya çalıştığını (\%50), etkinlikleri yerine getirmek için zamanı iyi kullandığını (\%42.9) ve çalışırken yaşadığı sorunları genellikle çözdüğünü (\%50) ifade etmektedir. Öğrencilerin üçte birinden fazlası ise çevrimiçi öğrenme ortamlarında ara sıra iletişim araçlarını kullanmanın yalnız olmadığını hissettirdiğini (\%42.9) ve öğretim materyallerine istediği zaman kolaylıkla ulaşabildiğini (\%35.7) ifade etmektedir. Öğrencilerin dörtte bire yakını ise hiçbir zaman çevrimiçi öğrenme ortamlarında arkadaşlarıyla daha rahat iletişim kuramadığını (\%21.4), ders çalışmanın çok hoşuna gitmediğini (\%23.8) ve daha iyi öğrendiğini düşünmediğini (\% 28.6) ifade etmektedir.

Harmanlanmış öğrenme ortamına yönelik öğrencilerin cevapları incelendiğinde öğrencilerin yarısına yakını her zaman harmanlanmış öğrenme ortamlarında ders içeriğinin açık ve anlaşılır olduğunu (\%45.2), ders içeriğinin planlı bir şekilde sunulduğunu (\%50), her iki ortamın üstün özelliklerinin kullanıldığını $(\% 45,2)$ ve eğer ihtiyaç duyarsa sınıf arkadaşlarıyla yüz yüze görüşmeye çalışacağını $(\% 45,2)$ ifade etmektedir. Öğrencilerin yarısının sık sık harmanlanmış öğrenme ortamlarında öğretim elemanının yüz yüze ve çevrimiçi ortamları etkili bir şekilde 
kullandığını (\%52.4), öğretim elemanından aldığı danışmanlık hizmetini yeterli gördüğünü (\%52.4), öğretim elemanının yüz yüze ve çevrimiçi ortamları yönetme konusunda başarılı olduğunu (\%54.8), çevrimiçi ve yüz yüze ortamlara ayrılan sürenin uygun olduğunu (\%54.8) ve öğretim etkinliklerini gerçekleştirirken zamanı iyi yönetebildiklerini (\%52.4) ifade etmektedir.

Öğrencilerin üçte birinin teknik boyutlarda her zaman internet bağlantısı ile ilgili sorunlar yaşadığını (\%33.3) ifade etmektedir. Öğrencilerin üçte biri ise teknik boyutlarda sık sık verilen ödevleri zamanında teslim etmekte zorlandığını (\%28.6) ve teknik anlamda zorluklar yaşadığını (\%38.1) ifade etmektedir. Öğrencilerin üçte biri de ara sıra teknik boyutlarda kendini yalnız ve mutsuz hissettiğini (\%33.3) ve teknolojik altyapı nedeniyle sorun yaşadığını (\%33.3) ifade etmektedir.

Tablo 4. Harmanlanmış Öğrenme Ortamları Ölçeği Maddelerine İlişkin Yüzde Değerleri

\begin{tabular}{|c|c|c|c|c|c|c|c|}
\hline Maddeler & Hiç & $\mathrm{N}$ & A & S & Her & M & SD \\
\hline $\begin{array}{l}\text { Yüz Yüze Öğrenme Ortamlarında öğretim elemanından çevrimiçi ortama göre } \\
\text { daha çok yararlanabildim. }\end{array}$ & 0 & 4.8 & 7.1 & 31 & 57.1 & 4.40 & .83 \\
\hline $\begin{array}{l}\text { Yüz Yüze Öğrenme Ortamlarında öğretim elemanından çevrimiçi ortama göre } \\
\text { daha çok yardım alabildim. }\end{array}$ & 0 & 2.4 & 9.5 & 33.3 & 54.8 & 4.40 & .77 \\
\hline Yüz Yüze Öğrenme Ortamlarında daha iyi öğrendiğimi düşünüyorum & 0 & 7.1 & 16.7 & 11.9 & 64.3 & 4.33 & 1.00 \\
\hline Yüz Yüze Öğrenme Ortamlarında arkadaşlarımla daha rahat iletişim kurdum. & 0 & 0 & 7.1 & 16.7 & 76.2 & 4.69 & .60 \\
\hline $\begin{array}{l}\text { Yüz Yüze Öğrenme Ortamlarında belirlediğim hedeflere ulaşmak benim için } \\
\text { önemlidir. }\end{array}$ & 0 & 0 & 4.8 & 19 & 76.2 & 4.71 & .55 \\
\hline $\begin{array}{l}\text { Yüz Yüze Öğrenme Ortamlarında öğretim elemanı rehberliğinde öğrenmem } \\
\text { motivasyonumu artırdı }\end{array}$ & 0 & 0 & 9.5 & 23.8 & 66.7 & 4.57 & .67 \\
\hline $\begin{array}{l}\text { Yüz Yüze Öğrenme Ortamlarında öğretim elemanı ile daha rahat iletişim } \\
\text { kurabildim. }\end{array}$ & 0 & 2.4 & 9.5 & 23.8 & 64.3 & 4.50 & .77 \\
\hline $\begin{array}{l}\text { Yüz Yüze Öğrenme Ortamlarında çevrimiçi ortamlara göre daha fazla } \\
\text { sorumluluk duygusu hissediyorum. }\end{array}$ & 0 & 4.8 & 21.4 & 21.4 & 52.4 & 4.21 & .95 \\
\hline $\begin{array}{l}\text { Yüz Yüze Öğrenme Ortamlarında öğretim elemanı derse katılmam için teşvik } \\
\text { etti. }\end{array}$ & 0 & 0 & 11.9 & 33.3 & 54.8 & 4.43 & .70 \\
\hline $\begin{array}{l}\text { Yüz Yüze Öğrenme Ortamlarında yaptığım ödevler ve araştırmalar konuyu } \\
\text { kavramam için yeterliydi. }\end{array}$ & 0 & 0 & 9.5 & 45.2 & 45.2 & 4.36 & .66 \\
\hline $\begin{array}{l}\text { Çevrimiçi Öğrenme Ortamlarında ders içeriğinin etkileşimli sunulması derse } \\
\text { olan ilgimi arttırdı. }\end{array}$ & 4.8 & 16.7 & 40.5 & 26.2 & 11.9 & 3.24 & 1.03 \\
\hline $\begin{array}{l}\text { Çevrimiçi Öğrenme Ortamlarında düzenlenen eş zamanlı (sohbet) } \\
\text { etkinliklerin daha iyi öğrenmemi sağladığını düşünüyorum. }\end{array}$ & 7.1 & 16.7 & 28.6 & 31 & 16.7 & 3.33 & 1.16 \\
\hline $\begin{array}{l}\text { Çevrimiçi Öğrenme Ortamlarında düzenlenen farklı zamanlı (tartışma vb.) } \\
\text { etkinliklerin daha iyi öğrenmemi sağladığını düşünüyorum. }\end{array}$ & 9.5 & 21.4 & 28.6 & 28.6 & 11.9 & 3.12 & 1.17 \\
\hline $\begin{array}{l}\text { Çevrimiçi Öğrenme Ortamlarında öğretim elemanı derse katılmam için teşvik } \\
\text { etti. }\end{array}$ & 9.5 & 9.5 & 26.2 & 33.3 & 21.4 & 3.48 & 1.21 \\
\hline Çevrimiçi Öğrenme Ortamlarında arkadaşlarımla daha rahat iletişim kurdum. & 21.4 & 11.9 & 40.5 & 19 & 7.1 & 2.79 & 1.20 \\
\hline Çevrimiçi Öğrenme Ortamlarında ders çalışmak çok hoşuma gitti. & 23.8 & 21.4 & 23.8 & 21.4 & 9.5 & 2.71 & 1.31 \\
\hline $\begin{array}{l}\text { Çevrimiçi Öğrenme Ortamlarında teknolojiyi kullanmak benim derse karşı } \\
\text { olan ilgimi artırdı. }\end{array}$ & 16.7 & 16.7 & 35.7 & 14.3 & 16.7 & 2.98 & 1.30 \\
\hline $\begin{array}{l}\text { Çevrimiçi Öğrenme Ortamlarında yüz yüze ortama göre daha çok sorumluluk } \\
\text { duygusu hissettim. }\end{array}$ & 14.3 & 7.1 & 28.6 & 19 & 31 & 3.45 & 1.38 \\
\hline $\begin{array}{l}\text { Çevrimiçi Öğrenme Ortamlarında iletişim araçlarını (internet, e-posta, } \\
\text { tartışma listeleri vb.) kullanmak yalnız olmadığımı hissettirdi. }\end{array}$ & 11.9 & 7.1 & 42.9 & 28.6 & 9.5 & 3.17 & 1.10 \\
\hline $\begin{array}{l}\text { Çevrimiçi Öğrenme Ortamlarında iş birliğine dayalı etkinliklere katılmaktan } \\
\text { hoşlandım. }\end{array}$ & 16.7 & 4.8 & 28.6 & 38.1 & 11.9 & 3.24 & 1.25 \\
\hline $\begin{array}{l}\text { Çevrimiçi Öğrenme Ortamlarında öğretim elemanından istediğim zaman } \\
\text { yardım alabildim. }\end{array}$ & 7.1 & 11.9 & 28.6 & 28.6 & 23.8 & 3.50 & 1.19 \\
\hline
\end{tabular}




\begin{tabular}{l} 
Maddeler \\
\hline Çevrimiçi Öğrenme Ortamlarında ders çalışırken sorularıma iletişim araçları \\
kullanarak yanıt aramaya çalıştım. \\
Çevrimiçi Öğrenme Ortamlarında öğretim elemanından anında dönüt \\
alabildim. \\
Çevrimiçi Öğrenme Ortamlarında etkinlikleri yerine getirmek için zamanı iyi \\
kullandım. \\
Çevrimiçi Öğrenme Ortamlarında daha iyi öğrendiğimi düşünüyorum. \\
Çevrimiçi Öğrenme Ortamlarında çalışırken yaşadığım sorunları genellikle \\
çözdüm. \\
Çevrimiçi Öğrenme Ortamlarında öğretim elemanı ile daha rahat iletişim \\
kurdum. \\
Çevrimiçi Öğrenme Ortamlarında öğretim materyallerine istediğim zaman \\
kolaylıkla ulaşabildim. \\
Çevrimiçi Öğrenme Ortamlarında yer alan çevrimiçi kaynaklar beklentilerimi \\
karşıladı. \\
Çevrimiçi Öğrenme Ortamlarında ders içeriği bireysel farklılıkları dikkate \\
alarak hazırlanmıştı.
\end{tabular}

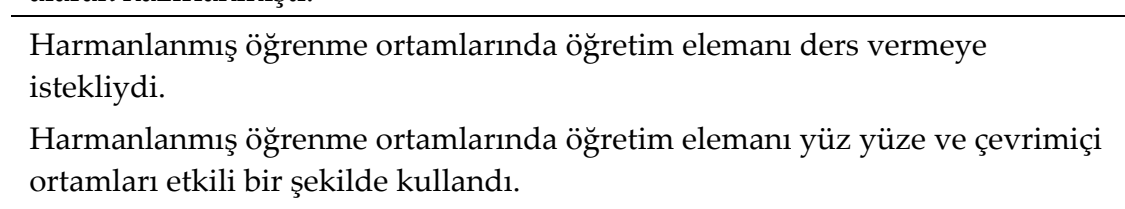

Harmanlanmış öğrenme ortamlarında öğretim elemanından aldığım danışmanlık hizmeti yeterliydi.

Harmanlanmış öğrenme ortamlarında daha iyi öğrendiğimi düşünüyorum.

Harmanlanmış öğrenme ortamlarında deneyimin önemli olduğunu

düşünüyorum.

Harmanlanmış öğrenme ortamlarında öğretim elemanı yüz yüze ve çevrimiçi ortamları yönetme konusunda başarılıydı.

Harmanlanmış öğrenme ortamlarında çevrimiçi ve yüz yüze ortamlara ayrılan süre benim için uygundu.

Harmanlanmış öğrenme ortamlarında dersin içeriği seviyeme uygundu.

Harmanlanmış öğrenme ortamlarında ders içeriği açık ve anlaşılırdı.

Harmanlanmış öğrenme ortamlarında ders içeriği planlı bir şekilde sunuldu.

Harmanlanmış öğrenme ortamlarında yüz yüze ve çevrimiçi olarak

gördüğümüz içerik seçilen ortama uygundu.

Harmanlanmış öğrenme ortamlarında her iki ortamın üstün özellikleri kullanıldı.

Harmanlanmış öğrenme ortamlarında sunulan öğrenme materyalleri benim için yeterliydi.

Harmanlanmış öğrenme ortamlarında kullanılan farklı öğretim yöntem ve teknikleri içeriğin aktarılması için uygundu.

Harmanlanmış öğrenme ortamlarında her iki ortamda aktarılan içerikte bir bütünlük vardı.

Harmanlanmış öğrenme ortamlarında hangi ölçütlere göre

değerlendirileceğim önceden belirtildi.

Harmanlanmış öğrenme ortamlarında başarımın değerlendirilmesi için farklı değerlendirme teknikleri kullanılmasını isterim.

Harmanlanmış öğrenme ortamlarında eğer ihtiyaç duyarsam sınıf arkadaşlarımla yüz yüze görüşmeye çalışırım.

Harmanlanmış öğrenme ortamlarında öğretim etkinliklerini gerçekleştirirken zamanı iyi yönetebildim.

\begin{tabular}{|c|c|c|c|c|c|c|}
\hline Hiç & $\mathrm{N}$ & A & $S$ & Her & $\mathrm{M}$ & $\mathrm{SD}$ \\
\hline 4.8 & 0 & 11.9 & 50 & 33.3 & 4.07 & .95 \\
\hline 4.8 & 14.3 & 28.6 & 28.6 & 23.8 & 3.52 & 1.15 \\
\hline 4.8 & 2.4 & 19 & 42.9 & 31 & 3.93 & 1.02 \\
\hline 28.6 & 38.1 & 9.5 & 16.7 & 7.1 & 2.36 & 1.27 \\
\hline 4.8 & 7.1 & 23.8 & 50 & 14.3 & 3.62 & .99 \\
\hline 14.3 & 23.8 & 28.6 & 28.6 & 4.8 & 2.86 & 1.14 \\
\hline 14.3 & 21.4 & 35.7 & 21.4 & 7.1 & 2.86 & 1.14 \\
\hline 7.1 & 14.3 & 31 & 35.7 & 11.9 & 3.31 & 1.09 \\
\hline 7.1 & 19 & 31 & 26.2 & 16.7 & 3.26 & 1.17 \\
\hline 4.8 & 0 & 11.9 & 45.2 & 38.1 & 4.12 & .97 \\
\hline 2.4 & 0 & 11.9 & 52.4 & 33.3 & 4.14 & .81 \\
\hline 2.4 & 0 & 9.5 & 52.4 & 35.7 & 4.19 & .80 \\
\hline 11.9 & 7.1 & 35.7 & 40.5 & 4.8 & 3.19 & 1.06 \\
\hline 4.8 & 0 & 14.3 & 38.1 & 42.9 & 4.14 & 1.00 \\
\hline 2.4 & 0 & 11.9 & 54.8 & 31 & 4.12 & .80 \\
\hline 2.4 & 4.8 & 19 & 54.8 & 19 & 3.83 & .88 \\
\hline 4.8 & 2.4 & 11.9 & 38.1 & 42.9 & 4.11 & 1.04 \\
\hline 2.4 & 0 & 9.5 & 42.9 & 45.2 & 4.29 & .83 \\
\hline 2.4 & 2.4 & 11.9 & 33.3 & 50 & 4.26 & .94 \\
\hline 4.8 & 0 & 19 & 35.7 & 40.5 & 4.07 & 1.02 \\
\hline 4.8 & 0 & 19 & 31 & 45.2 & 4.12 & 1.04 \\
\hline 4.8 & 2.4 & 33.3 & 35.7 & 23.8 & 3.71 & 1.02 \\
\hline 2.4 & 0 & 35.7 & 31 & 31 & 3.88 & .94 \\
\hline 4.8 & 0 & 28.6 & 33.3 & 33.3 & 3.90 & 1.03 \\
\hline 9.5 & 0 & 28.6 & 38.1 & 23.8 & 3.67 & 1.14 \\
\hline 2.4 & 7.1 & 16.7 & 35.7 & 38.1 & 4 & 1.04 \\
\hline 4.8 & 2.4 & 4.8 & 42.9 & 45.2 & 4.21 & 1.00 \\
\hline 4.8 & 0 & 23.8 & 52.4 & 19 & 3.81 & .92 \\
\hline
\end{tabular}




\begin{tabular}{|c|c|c|c|c|c|c|c|}
\hline Maddeler & Hiç & $\mathrm{N}$ & A & S & Her & M & SD \\
\hline $\begin{array}{l}\text { Harmanlanmış öğrenme ortamlarında neyi nasıl öğreneceğime kendim karar } \\
\text { verdim. }\end{array}$ & 4.8 & 0 & 23.8 & 47.6 & 23.8 & 3.86 & .95 \\
\hline Teknik Boyutlarda kendimi yalnız ve mutsuz hissettim. & 16.7 & 19 & 33.3 & 9.5 & 21.4 & 3 & 1.36 \\
\hline Teknik Boyutlarda verilen ödevleri zamanında teslim etmekte zorlandım. & 11.9 & 11.9 & 28.6 & 28.6 & 19 & 3.31 & 1.26 \\
\hline Teknik Boyutlarda teknolojik altyapı nedeniyle sorun yaşadım. & 9.5 & 14.3 & 33.3 & 21.4 & 21.4 & 3.31 & 1.24 \\
\hline Teknik Boyutlarda teknik anlamda zorluklar yaşadım & 14.3 & 9.5 & 16.7 & 38.1 & 21.4 & 3.43 & 1.33 \\
\hline Teknik Boyutlarda internet bağlantısı ile ilgili sorun(lar) yaşadım. & 11.9 & 11.9 & 19 & 23.8 & 33.3 & 3.55 & 1.38 \\
\hline
\end{tabular}

(Her=Her zaman, S=Sık sık, N=Nadiren, A=Ara sıra, Hiç=Hiçbir zaman)

Öğrencilerin WTPDÖ tutum ve harmanlanmış öğrenme ortamları ölçeklerinin alt faktörleri arasındaki korelasyon değerleri Tablo 5'te verilmiştir. Bu tablo incelendiğinde fen laboratuvarına ilişkin tutum ile teknik boyutlar arasında negatif ilişki bulunmuştur (r=-0.312). İşbirliğine dayalı öğrenme ile yüz yüze öğrenme ortamları arasında pozitif ilişki bulunmuştur(r=0.391). Web'e dayalı öğrenme ile çevrimiçi öğrenme ortamları (r=0.413) ve harmanlanmış öğrenme ortamları ( $\mathrm{r}=0.387)$ arasında pozitif ilişki bulunurken, teknik boyutlar arasında ( $\mathrm{r}=-0.417)$ negatif ilişki bulunmuştur. Problem çözme ile yüz yüze öğrenme ortamları arasında pozitif ilişki bulunmuştur $(\mathrm{r}=0.380)$.

Tablo 5. WTPDÖ Tutum ve Harmanlanmış Öğrenme Ortamları Ölçeklerinin alt faktörleri arasındaki korelasyon değerleri

\begin{tabular}{|c|c|c|c|c|c|c|c|c|}
\hline Alt boyutlar & 2 & 3 & 4 & 5 & 6 & 7 & 8 & 9 \\
\hline 1.Fen lab & $.368^{*}$ & $.598^{* *}$ & .168 & .268 & -.007 & .154 & .223 & $-.312^{*}$ \\
\hline 2.İssbirliğine Dayalı öğrenme & & $.407^{* *}$ & $.369^{*}$ & $.411^{* *}$ & $.391^{*}$ & .010 & .246 & -.162 \\
\hline 3.Web'e dayalı öğrenme & & & .149 & .272 & -.141 & $.413^{* *}$ & $.387^{*}$ & $-.417^{* *}$ \\
\hline 4.Kendi kendine öğrenme & & & & $.332^{*}$ & .294 & -.187 & .052 & -.207 \\
\hline 5.Problem çözme & & & & & $.380^{*}$ & .008 & .215 & -.086 \\
\hline 6. Yüz yüze öğrenme ortamları & & & & & & $-.397^{* *}$ & -.065 & .091 \\
\hline 7.Çevrimiçi öğrenme ortamları & & & & & & & $.628^{* *}$ & $-.308^{*}$ \\
\hline 8.Harmanlanmış öğrenme ortamları & & & & & & & & $-.445^{* *}$ \\
\hline 9. Teknik boyutlar & & & & & & & & \\
\hline
\end{tabular}

* Korelasyon 0.05 düzeyinde anlamlı

** Korelasyon 0.01 düzeyinde anlaml

Korelasyon katsayı değeri 0.20 - 0.39 arasında ise zayıf ilişki, 0.40 - 0.59 arasında ise orta düzeyde ilişki olarak ifade edilmektedir (Cohen, 1988, pp. 79-91). Pozitif ilişki gösteren korelasyon değerlerine göre iş birliğine dayalı öğrenmeye yönelik tutum puanları artarken, yüz yüze öğrenme ortamlarının da etkililiğine yönelik görüşlerinde arttığ1 görülmektedir ( $\mathrm{r}=0.391)$. Web'e dayalı öğrenmeye yönelik tutum puanları artarken, çevrimiçi ve harmanlanmış öğrenme ortamlarının etkililiğine yönelik görüş puanlarının da arttı ̆̆ı belirlenmiştir (r=0.413, r=0.387). Problem çözmeye yönelik tutum puanları artarken, yüz yüze öğrenme ortamlarının etkililiğinin de arttı̆̆ belirlenmiştir (r=0.380). Ayrıca negatif ilişki gösteren korelasyon değerlerine göre teknik boyutlarda sorunların artmasıyla fen laboratuvarına ilişkin tutumun ve Web'e dayalı öğrenmenin etkililiğinin azaldığı belirlenmiştir (r=0.312, r=-0.417). Ek olarak teknik boyutlardaki sorunların artması ile hem çevrimiçi hem de harmanlanmış öğrenme ortamlarının etkililiğinin azaldığı görülmektedir.

\section{Uzaktan eğitim ile ilgili öğrenci görüşleri}

Öğrencilerin uzaktan eğitime yönelik olumlu görüşlerini toplamak için “Uzaktan eğitimin olumlu bulduğunuz yönleri nelerdir?" sorusu sorulmuştur. Öğrencilerin uzaktan eğitime yönelik olumlu görüşlerine ilişkin söylemleri sinıflandırıldığında aşağıda örnek söylemler ve bu söylemlere ait sıklıklar Tablo 6’da sunulmuştur.

Tablo 6. Olumlu özellikler

\begin{tabular}{lccl}
\hline Kodlar & $f$ & $\%$ & Öğrenci Söylemleri \\
\hline Derslerin tekrar izlenebilmesi & 15 & 28 & $\begin{array}{l}\text { Dersleri tekrar izleyebiliyor olmak en olumlu yönü. (Ö1) } \\
\text { Ders kayıtlarını sonradan izleyebilmek. (Ö6) }\end{array}$ \\
\hline
\end{tabular}

|Manisa Celal Bayar University Journal of The Faculty of Education, 2021, Vol. 9, No. 1| 


\begin{tabular}{lll}
\hline Kodlar & \% & Öğrenci Söylemleri \\
\hline & Derslerin tekrar izlenebilmesi çok yararlı oldu. (Ö12) \\
& Sonradan dersi bir daha dinlemek. (Ö17) \\
& Daha sonra açıp tekrar izleyip anlamadığımız yerleri tekrar etmek. (Ö21) \\
& Anlaşılmayan kısılmları başa sarabilmek, tekrar etmek.(Ö23)
\end{tabular}

Anlaşılmayan kısımları başa sarabilmek, tekrar etmek.(Ö23)

Zaman ve mekân sınırlaması yok. (Ö8)

Okula gitmek için uzun bir yol çekmek zorunda kalmadım. (Ö10)

Fen laboratuvar dersinde evdeki malzemelerle yapılabilecek deneyler için malzemeleri okula taşımayıp evde yapmamız zaman açısından olumlu

Zaman açısından tasarruf sağlaması
8

15 yönlerindendi. (Ö19)

Yol ve mesafe yorgunluğu çekmeden daha kısa ve rahat erişim sağlamam. (Ö27)

Zamandan tasarruf edilir. (Ö35)

Yol ve hazırlanma için zaman kaybı yaşamıyoruz. (Ö37)

Zaman sıkıntısı konusunda olumlu bir eğitim. (Ö38)

\section{Ödev yapma bilincini geliştirmesi}

Ödev yapma bilincimi geliştirdi. (Ö11)

713 Sinavlar yerine ödevlendirme yapılması benim için olumluydu. (Ö25) Ödevlendirme yapılması. (Ö26)
Uzaktan eğitim sayesinde verilen çalışmaları kendi imkânlarımızla

Kendi öğrenmelerinin sorumluluğunu alması

$5 \quad 9$

öğrenmeye çalıştık. Sorumluluk bilincim arttı. (Ö12)
Grup ödevleri de olsa bireysel de olsa bize daha fazla sorumluluk düşüyor. (Ö36)

Biz öğrenciler için ilerideki meslek yaşantımızda bize deneyim kattığını düşünüyorum. (Ö8)

Teknolojiyi aktif kullanmanın mesleki deneyim katması

9 Teknolojiyi aktif kullanmak mesleğimiz için gerekli olduğundan bizlere fayda sağlayacaktır. (Ö9) Teknolojiyi kullanabilmemizi sağlar. (Ö29)

Deneyleri ve dersleri daha çok araştırarak yapmak daha çok öğrenmemizi sağladı. (Ö10)

Araştırma yapmanın daha çok öğrenmeyi sağlaması

Kendimiz çaba gösterdiğimiz için öğrenmenin daha kalıcı olduğunu düşünüyorum. (Ö12)

Grup ödevleri de olsa bireysel de olsa daha fazla araştırıp öğrenebiliyoruz. (Ö36)

Salgın gibi süreçlerde dönem kaybetmemeyi sağladı. (Ö3)

Uzaktan eğitim yüz yüze eğitim sağlanamadığında iyi bir alternatif çözüm

Salgın gibi süreçlerde eğitimin devamlılığının sağlaması

\section{$4 \quad 8 \quad$ olabilir. (Ö9)}

Örgün eğitimin olamayacağı zamanlarda dışarı çıkma gibi kısıtlı dönemlerde eğitimin devam ettirilmesi. (Ö39)

\begin{tabular}{lccl}
\hline Evde ailenin yanında olmak & 3 & 6 & $\begin{array}{l}\text { Ailemin yanında olmak. Sıcak havalarda dışarı çıkmaktansa oturduğum } \\
\text { yerde çalışmak güzel. Ö15) } \\
\text { Ailemin yanında olduğum için uzaktan eğitim rahat bir öğrenme modelidir. } \\
\text { (Ö10) }\end{array}$ \\
\hline Covid -19 tehlikesi olmaması & 1 & 2 & Covid -19 tehlikesi olmadı. (Ö32) \\
\hline $\begin{array}{l}\text { Pandemi döneminde } \\
\text { sosyalleşmeyi sağlaması }\end{array}$ & 1 & 2 & Sosyalleşme konusunda yarar sağlayabilir. (Ö9) \\
\hline Toplam & 53 & 100 & \\
\hline
\end{tabular}

Tablo 6 incelendiğinde, öğrencilerin uzaktan eğitimin olumlu yönü olarak en çok derslerin tekrar izlenebilmesi ( $\mathrm{f}=15$ ) olduğu görülmektedir. Diğer olumlu yönleri ise zaman açısından tasarruf sağlaması ( $\mathrm{f}=8$ ), ödev yapma bilincini geliştirmesi ( $f=7)$, kendi öğrenmelerinin sorumluluğunu alması ( $f=5$ ), teknolojiyi aktif kullanmanın mesleki deneyim katması ( $f=5)$, araştırma yapmanın daha çok öğrenmeyi sağlaması (f=4), salgın gibi süreçlerde eğitimin devamlılığını sağlaması $(\mathrm{f}=4)$ ve evde ailenin yanında olmak ( $\mathrm{f}=3)$ olarak ifade etmektedir. Az sayıda öğrenci ise Covid -19 tehlikesi olmaması $(\mathrm{f}=1)$ ve pandemi döneminde sosyalleşmeyi sağlaması (f=1) yönlerini uzaktan eğitimin olumlu yönü olarak görmektedir. 
Öğrencilerin uzaktan eğitime yönelik olumsuz görüşlerini toplamak için “Uzaktan eğitimin olumsuz bulduğunuz yönleri nelerdir?" sorusu sorulmuştur. Öğrencilerin uzaktan eğitime yönelik olumsuz görüşlerine ilişkin söylemleri sınıflandırıldığında aşağıda örnek söylemler ve bu söylemlere ait sıklıklar Tablo 7'de sunulmuştur.

Tablo 7. Olumsuz özellikler

\begin{tabular}{|c|c|c|c|}
\hline Kodlar & $f$ & $\%$ & Öğrenci Söylemleri \\
\hline $\begin{array}{l}\text { Teknik sorunlar ve internet } \\
\text { kaynaklı sorunların olması }\end{array}$ & 25 & 26 & $\begin{array}{l}\text { Teknolojik açıdan olumsuzdu. (Ö2) } \\
\text { Internet bağlantısında çok sıkıntı yaşıyorum. (Ö6) } \\
\text { Uzaktan eğitimde internet sıkıntısından dolayı aksaklıklar olabilir. (Ö9) } \\
\text { Çoğu zaman internet sıkıntısı yaşayıp derse girememek. (Ö10) } \\
\text { Herkesin evde olduğu bu dönemde internet kopukluğu ya da internet hız } \\
\text { düşüklüğü sebebiyle derslere aktif katılım sağlayamamak. (Ö11) } \\
\text { İnternet bağlantısı sorunu yaşayabiliyoruz. (Ö18) } \\
\text { Bilgisayar açısından az da olsa sıkıntılar yaşadım. (Ö19) } \\
\text { Internet sıkıntısı olduğu için derslere girmekte zorlandım. (Ö20) } \\
\text { İnternet çekmediği zamanlar derslere katılamadım. (Ö26) } \\
\text { İnternet vb. sorunlardan derslere zamanında katılamıyoruz. (Ö34) }\end{array}$ \\
\hline
\end{tabular}

Kısaca verimli bulmuyorum. (Ö7)

Grup çalışmalarının yüz yüze eğitimde daha etkili olduğunu düşünüyorum.

Grup çalışmalarının yüz yüze eğitime göre etkisiz olması

1515 Etkili ders işlenmiyor. (Ö18)

Yüz yüze olan ortam kadar etkili değil. (Ö28)

Yüz yüze eğitimdeki kadar verimli değil. (Ö29)

Uygulama derslerinde yeterince verimli değildir. (Ö35)

İletişimin yüz yüze eğitimdeki kadar sağlıklı olmadığını düşünüyorum. (Ö9) Öğretmenlerimizle daha yakından iletişim kurma şansımız oldu sorularımızı aninda sorduk. (Ö14)

İletişim eksikliği olması

1212 Hocamızla iletişimimiz zayıf kalabiliyor. (Ö18)

Yüz yüze öğrenmedeki gibi sorular sorulamaması. (Ö21)

Derslerde soru soramama çekimserlik oldu. (Ö22)

Yüz yüze eğitim kadar etkileşimli iletişim sağlanamıyor. (Ö34)

Eğitimde fırsat eşitliğini ortadan kaldırdı, imkânı olmayan arkadaşlar döneme devam edemedi. (Ö3)

İnternet hızının yükselmesi ve öğrencilere eşit ve gerekli imkânlar sunulmalıdır. (Ö12)

Benim için hiçbir olumlu yanı olmadı çünkü derslere ulaşmam için elimde

Eğitimde fırsat eşitsizliği yaratmas1

hiçbir imkân yoktu. (Ö33)

Benim gibi kırsal kesimde olup da internet bulamayan imkân bulamayan mesela bir deney yapmak istediğimizde gerekli malzemeleri bulamayan çok kişi vardır. Ben ve benim gibi durumu yaşayanlar bu durumdan çok olumsuz etkilenirler. (Ö34)

İnternete ulaşım herkes için eşit değildir. (Ö35)

Her öğrencide teknolojik cihaz olmaması. (Ö39)

Yüz yüze derslerdeki gibi derse adapte olunamiyor. (Ö8)

Sınıf ortamındaki motivasyon uzaktan eğitim sürecinde daha az. (Ö9)

Konsantrasyon, motivasyon eksikliği olması

99 Dersleri dinlerken tam motive olamadım. (Ö19)

Yüz yüze eğitimde olduğu kadar dikkatli ve konsantre değiliz. (Ö37) İlgi çekici değil odaklanmak zor. (Ö38)

Normal yüz yüze sınavda çok daha rahatken bu dönemde ödev yoğunluğu ve sınavlar yüzünden çok strese girdim. Bu da benim uyuyamama sebep oldu.

Çok fazla ödev ve iş yükünün stres oluşturması

$8 \quad 8$ Yıprandım açıkçası. (Ö1)

Yüz yüze eğitime göre hocalar daha çok ödev verdi ve zorladı. Bu da strese sebep oldu. (Ö2)

Fazlasıyla ödevlendirme yapılması strese sebep oldu. (Ö15)

Yüz yüze eğitim kadar sorumluluk almaya teşvik etmemesi
Daha çok çaba göstermek için elimden geleni yapmadım. (Ö14)

55 Kendi kendime disiplini sağlayamadım. (Ö24)

Yüz yüze eğitim kadar sorumluluk almaya teşvik etmiyor. (Ö30)

|Manisa Celal Bayar University Journal of The Faculty of Education, 2021, Vol. 9, No. 1| 


Kodlar
Çevrimiçi derse katılamamak
ve geriden gelmek

ve geriden gelmek

Sağlık sorunları

Sınavların adil olmaması $3 \quad 3 \quad \begin{aligned} & \text { olasilığı çok yüksek. Mesela, birinin ailesinden biri } \\ & \text { sınavı olsa yardım edebilir. (Ö1) } \\ & \text { Değerlendirme kısmında eksik kalmaktadır. (Ö35) }\end{aligned}$

$f \quad \% \quad$ Öğrenci Söylemleri

44 Derse aktif bir şekilde katılmayıp sonradan dinlemek (geriden gelmek). (Ö15)

Şartlar neticesinde derslerin çoğunu takip edememe. (Ö42)

Sınav yapan hocalar oldu, adil olduğunu düşünmüyorum. Çünkü kopya

Zor bir süreçten geçerken çok fazla bir anda yüklenmiş ödevler biraz psikolojik

$33 \begin{aligned} & \text { durumları bozdu. (Ö1) } \\ & \text { Sadece bilgisayar, telefon vb. araçlardan yararlandığımız için gözlerimiz ve }\end{aligned}$

başımız ağrıyor. Bu şekilde ödevlerin de bir kısmından sonra kopuyoruz. (Ö29)

\begin{tabular}{llrl}
$\begin{array}{l}\text { Aile ile yaşamanın getirdiği } \\
\text { sorumlulukların artması }\end{array}$ & 3 & 3 & $\begin{array}{l}\text { Evin büyüğü olarak sorumluluklarımın artması (ev işleri gibi). (Ö15) } \\
\text { Ev ortamında olmak öğrenmeyi daha da güç hale getirdi. (Ö22) } \\
\text { Evde olunmasından dolayı öğrenci sorumluluğunun artması. (Ö42) }\end{array}$ \\
\hline
\end{tabular}

Çalışma ortamının olmaması $\quad 1 \quad 1 \quad$ Çalışma ortamının olmaması. (Ö15)

Toplam $98 \quad 100$

Tablo 7 incelendiğinde öğrencilerin uzaktan eğitime yönelik olumsuz olarak teknik sorunlar ve internet kaynaklı sorunların olması ( $\mathrm{f}=25)$, grup çalışmalarının yüz yüze eğitime göre etkisiz olması ( $\mathrm{f}=15$ ), iletişim eksikliği olması ( $\mathrm{f}=12)$ ve eğitimde fırsat eşitsizliği yaratması $(\mathrm{f}=10)$ görüşleri olduğu görülmektedir. Ayrıca, öğrenciler uzaktan eğitime ilişkin yaşadıkları diğer olumsuzlukları konsantrasyon, motivasyon eksikliği olması (f=9), çok fazla ödev ve iş yükünün stres oluşturması $(\mathrm{f}=8)$, yüz yüze eğitim kadar sorumluluk almaya teşvik etmemesi ( $\mathrm{f}=5$ ), çevrimiçi derse katılamamak ve geriden gelmek ( $\mathrm{f}=4)$ olarak ifade etmektedir. Az sayıda öğrencinin de sınavların adil olmaması ( $\mathrm{f}=3)$, sağlık sorunları $(\mathrm{f}=3)$, aile ile yaşamanın getirdiği sorumlulukların artması ( $\mathrm{f}=3$ ) ve çalışma ortamının olmaması ( $\mathrm{f}=1$ ) gibi olumsuzlukları uzaktan eğitimin olumsuz yönü olarak gördüklerini ifade etmektedir.

Öğrencilerin uzaktan eğitime yönelik olumlu ve olumsuz görüşleri karşılaştırıldığında öğrencilerin daha çok olumsuz görüşleri bildirdikleri görülmektedir. Uzaktan eğitimin olumlu yönü olarak derslerin tekrar izlenebilmesi ve zaman tasarrufu ön plana çıkarken, olumsuz yönü olarak teknik ve internet kaynaklı sorunların olması, grup çalışmalarının etkisizliği, iletişim eksikliği ve eğitimdeki fırsat eşitsizliğinin ön plana çıktığı görülmektedir.

\section{TARTIŞMA}

$\mathrm{Bu}$ çalışmada, probleme dayalı harmanlanmış öğrenme ortamının etkililiğine yönelik öğrenci tutumları WTPDÖ tutum ölçeği ve harmanlanmış öğrenme ortamı etkililiği ölçeği ile belirlenmiştir. Uygulama süreci sonunda öğrencilerin WTPDÖ tutum ölçeğine verdikleri cevaplara göre uygulama sürecine ilişkin olumlu tutuma sahip oldukları ortaya çıkmıştır. Ayrıca, öğrencilerin WTPDÖ tutum ölçeğinin alt faktörleri olan fen laboratuvar dersine, iş birliğine dayalı öğrenmeye, WEB'e dayalı öğrenmeye, kendi kendine öğrenmeye, problem çözmeye yönelik olumlu tutuma sahip oldukları sonucuna ulaşılmıştır. Öğrenci ortalamaları incelendiğinde öğrencilerin ölçeğin hem toplamından hem de alt faktörlerden aldıkları ortalama puanların orta değer olan 3.5 üzerinde olduğu görülmektedir. Alan yazındaki çalışmalar incelendiğinde benzer olarak fizik öğretmenliği bölümünde gerçekleştirilen harmanlanmış öğrenme çalışmasına katılan öğrencilerin internete, web tabanlı öğrenmeye ve bilgisayara yönelik olumlu tutumlarının geliştiği bulunmuştur (Şimşek, 2009). Pesen (2014) yaptığ1 çalışmada harmanlanmış öğretime katılan eğitim fakültesi öğrencilerinin motivasyon, başarı ve kendi kendine ders çalışma alışkanlıklarının arttığı sonucuna ulaşmıştır. Harmanlanmış öğrenmenin gerçekleştirildiği fen laboratuvarı dersine katılan fen bilgisi öğretmenliği öğrencilerinin derse yönelik olumlu tutum geliştirdikleri belirlenmiştir (Kirişçioğlu, 2009). Web üzerinden gerçekleştirilen PDÖ etkinliklerine katılan öğrencilerin yüz yüze PDÖ geçekleştirilen sinıftaki öğrencilere göre derse yönelik tutum, iş birliğine yönelik tutum, Web'e dayalı öğrenmeye yönelik tutum, kendi kendine öğrenmeye yönelik tutum ve problem çözmeye yönelik tutum puanlarının olumlu yönde yüksek çıtı̆̆ 1 belirlenmiştir (Günbatar, 2009). Altunçekiç (2010) lisans öğrencileri ile gerçekleştirdiği WTPDÖ sonucunda öğrencilerin problem çözme düzeyi, akademik başarı ve internet kullanmaya yönelik tutumlarının arttığını 
belirlemiştir. Karabatak ve Turhan (2017) öğretmenler ile yaptığı çalışmada web tabanlı probleme dayalı öğrenmenin öğretmenlerin ihtiyaçlarının karşıladığını ve tutumlarını anlamlı şekilde pozitif olarak arttırdığı bulunmuştur. Konu ve Gül (2017) web tabanlı probleme dayalı öğrenmenin biyoloji dersine yönelik öğrencilerin motivasyonlarını, tutumları ve problem çözme becerilerini arttırdığını bulmuştur. Alan yazındaki çalışmalar ile araştırma sonucunda elde edilen sonuçlar paralellik göstermektedir. Bu nedenle, probleme dayalı harmanlanmış öğrenmenin Fen laboratuvar dersinde ve uygun olan uygulamalı derslerde kullanılması öğrencilerin web tabanlı probleme dayalı öğrenmeye yönelik olumlu tutum geliştirmelerini sağlayabilir.

Öğrencilerin harmanlanmış öğrenme ortamının etkililiğine yönelik cevapları incelendiğinde harmanlanmış öğrenme ortamını etkili buldukları ve orta değer olan 3.5 değerinin üzerinde ortalamaya sahip oldukları belirlenmiştir. Ayrıca, harmanlanmış öğrenme ortamı etkililiği ölçeğinin alt faktörlerinden aldıkları puanlar incelendiğinde öğrencilerin Yüz yüze öğrenme ortamları ve Harmanlanmış öğrenme ortamları alt faktörlerinden orta değer olan 3.5 değerinden daha yüksek ortalama puanlar aldıkları, Çevrimiçi Öğrenme Ortamları ve Teknik boyutlar faktörlerinden ise orta değer olan 3.5 değerine daha yakın ortalama puanlar aldıkları belirlenmiştir. Alan yazındaki yapılan bir çalışmada öğretmen adaylarının laboratuvar dersinde katıldıkları harmanlanmış öğrenme ortamını etkili, işlevsel, pratik ve yenilikçi buldukları görülmektedir (Yılmaz, 2017). Sungur Alhan ve Şimşek (2020) fen bilgisi öğretmenliği öğrencileri ile yaptığı çalışmada harmanlanmış öğrenme ortamının gök cisimleri konusunda öğrencilerin teknolojik pedagojik alan bilgilerini olumlu yönde etkilediği sonucuna ulaşmıştır. Fen bilgisi öğretmenliği öğrencileri ile yapılan deneysel çalışmada harmanlanmış öğrenmeye katılan öğrencilerin ders çalışma alışkanlıklarının ve sorumluluklarının geliştiği görülmüştür (Aydemir, 2012). Aynı çalışma sonucunda öğrenciler ile yapılan görüşmelerde öğrenciler iletişim kurma açısından harmanlanmış öğrenmenin faydalı olduğunu ifade etmiştir. Fen laboratuvar dersinde gerçekleştirilen harmanlanmış öğrenmeye katılan öğrencilerin çalışma sonundaki görüşmelerde çevrimiçi uygulamaları faydalı gördükleri, harmanlanmış öğrenmenin konuyu kavrama, istenilen hızda ve zamanda öğrenmeye fırsat sunması açısından esnek ve yararlı gördükleri belirlenmiştir (Kirişçioğlu, 2009). Bireysel farklılıklara sahip öğrencilere yüz yüze öğrenme ile sosyal öğrenmenin yanında çevrimiçi öğrenme ortamlarıyla kendine uygun hız ve zamanda bireysel öğrenme fırsatı sunulmaktadır (Çardak, 2012). Ayrıca, alan yazındaki çalışmalarda maliyet, sosyal etkileşim, pedagojik zenginlik ve ulaşım kolaylığı açısından harmanlanmış öğrenmenin etkili olduğu ifade edilmektedir (Dağ, 2011; Osguthorpe ve Graham, 2003). Alan yazındaki çalışmalar ile araştırma sonundaki bulgular karşılaştırıldığında aralarında bir paralellik olduğu görülmektedir. Bu yüzden, probleme dayalı harmanlanmış öğrenme ortamının Fen laboratuvarı ve benzer derslerde uygulanmasının etkili olacağı görülmektedir. Ayrıca, öğrencilerin çevrimiçi ortamlarda yaşadıkları teknik sorunlar nedeniyle çevrimiçi ortamları ortalamaya yakın etkili gördükleri belirlenmiştir. Yüz yüze ve harmanlanmış öğrenme ortamlarını bu nedenle daha etkili gördükleri söylenebilir. Öğrencilerin yaşadıkları teknik aksaklıkların giderilmesi ve çevrimiçi deneyimlerinin arttırılması olumlu tutum geliştirmelerini sağlayabilir.

Öğrencilerin probleme dayalı harmanlanmış öğrenme ortamında yüz yüze ve çevrimiçi ortamdaki derslere katıldıktan sonraki uzaktan eğitime yönelik olumlu ve olumsuz görüşleri açık uçlu sorular ile belirlenmiştir. Öğrencilerin uzaktan eğitime yönelik olumsuz görüşleri olumlu görüşlerine göre daha fazla olduğu öğrenci cevaplarındaki kodlardan ve alıntılardan ortaya çıkarılmıştır. Öğrencilerin uzaktan eğitime yönelik dersleri tekrar izlenebilmesi, zaman açısından tasarruf sağlaması, ödev yapma bilincini geliştirmesi, kendi öğrenmelerinin sorumluluğunu almayı sağlaması, teknolojiyi aktif kullanmanın mesleki deneyim katması, araştırma yapmanın daha çok öğrenmeyi sağlaması, salgın gibi süreçlerde eğitimin devamlılığını sağlaması, evde ailenin yanında olmak, Covid-19 tehlikesi olmaması ve pandemi döneminde sosyalleşmeyi sağlaması açısından olumlu gördükleri belirlenmiştir. Ancak öğrencilerin uzaktan eğitimde teknik sorunlar ve internet kaynaklı sorunların olması, grup çalışmalarının yüz yüze eğitime göre etkisiz olması, iletişim eksikliği olması, eğitimde fırsat eşitsizliği yaratması, konsantrasyon ve motivasyon eksikliği olması, çok fazla ödev ve iş yükünün stres oluşturması, yüz yüze eğitim kadar sorumluluk almaya teşvik etmemesi, çevrimiçi derse katılamamak ve geriden gelmek, sınavların adil

|Manisa Celal Bayar University Journal of The Faculty of Education, 2021, Vol. 9, No. 1 | 
olmaması, sağlık sorunları, aile ile yaşamanın getirdiği sorumlulukların artması ve çalışma ortamının olmaması açısından olumsuz gördükleri belirlenmiştir.

Alan yazında yapılan çalışmalarda öğrencilerin uzaktan eğitime yönelik hem olumlu hem de olumsuz farklı görüşlerinin olduğu görülmektedir. Üniversite öğrencilerinin uzaktan eğitime yönelik görüşlerinin toplandığı bir çalışmada, öğrencilerin olumsuz olarak teknik problemler, aktif katılımın sağlanamaması, etkileşimin örgün eğitime oranla az olması ve devam zorunluluğunun olmaması gibi görüşleri ifade etmelerine rağmen tekrar etme olanağı, kendi hızında ve birebir öğrenme olanağı, rahat ve esnek bir öğrenme ortamı, teknolojiyi etkin kullanma, öğrenmeye destek olma gibi olumlu özelliklerinin daha çok olduğunu ifade etmektedir (Mercan, 2018). Ayrıca, Turgut (2011) öğrencilerin uzaktan eğitimde teknik sorunlar ve etkileşimden kaynaklı olumsuz görüşleri olduğunu ve bu aksaklıklarının giderilmesini önermektedir. Alan yazındaki, bir diğer çalışmada harmanlanmış öğrenmenin kaynaklara kolay erişim sağladığı, iş birliğine dayalı öğrenme için uygun olduğu ve bilgisayar teknolojilerini kullanmayı geliştirdiği belirlenmiştir (Graham, 2006). Sosyal medya destekli harmanlanmış öğrenmenin öğrencilerin derslerine yönelik öz yeterlilik ve öz düzenleme becerileri ile kendi sorumluluklarını almalarına olumlu etkisi olduğu alan yazındaki çalışmalarda bulunmuştur (Dursun, 2018; Shea ve Bidjerano, 2010). Akgündüz (2013) fen eğitiminde gerçekleştirdiği harmanlanmış öğrenmenin öğrencilerin tutum, başarı, motivasyon ve kendi kendine öğrenme becerilerini geliştirdiğini bulmuştur. Emlek ve Aktürkoğlu (2017) ikinci sınıf üniversite öğrencilerinin web tabanlı probleme dayalı öğrenmeye yönelik görüşlerinin olumlu olduğunu ve bu metodun onların özgüvenlerini, derse yönelik motivasyonlarını, problem çözme becerilerini, öğrenmede sorumluluk alma isteklerini, araştırma yapma isteklerini arttırdığını ve zamanı etkili kullanmalarını sağladığına yönelik ifadeleri olduğunu bulmuştur. Delialioğu ve Yıldırım (2008) harmanlanmış öğrenmenin öğrencilerin bilgilerinin kalıcılı̆̆ına, derse yönelik tutumlarına ve memnuniyetlerine olumlu katkısı olduğu sonucuna ulaşmıştır. Harmanlanmış öğrenme ortamında gerçekleştirilen eğitimlerde öğrencilerin öğretmenleri ile daha iyi etkileşim kurdukları, öğretmen desteğini daha kolay aldıkları, dersin hedef ve içeriğinden daha kolay haberdar oldukları görülmüştür (Usta, 2007). Covid 19 pandemisi nedeniyle harmanlanmış eğitime ve uzaktan eğitime geçiş sürecinde yapılan çalışmalar incelendiğinde öğretmenlerin, öğretmen adaylarınının ve ortaokul öğrencilerinin teknik sorunlar yaşadıkları, bilgisayar kullanma becerilerinin düşük olması, internete erişimin olmaması, ilk kez uzaktan eğitim deneyim gibi olumsuzluklardan dolayı uzaktan eğitimi olumsuz gördükleri belirlenmiştir (Bakioğlu ve Çevik, 2020; Çakın ve Külekçi Akyavuz, 2020; Karatepe, Küçükgençay ve Peker, 2020; Pınar ve Dönel Akgül, 2020). Ancak, mevcut koşullarda eğitimin sürekliliğinin sağlanması, iletişimin sağlanması, pratik oluşu, bilgi paylaşımının hızlı olması, araştırmaya teşvik etmesi, derse hazırlıklı gelme, işbirlikli öğrenmeyi sağlaması gibi faydalardan dolayı olumlu görüşlerin olduğuna görülmektedir (Kadirhan ve Korkmaz, 2020; Sungur Alhan ve Şimşek, 2020; Yılmaz, 2017). Alan yazındaki çalışmalar incelendiğinde uzaktan eğitimin bu çalışmadaki gibi ilk defa uzaktan eğitime katılan veya uzaktan eğitim deneyimi az olan öğrencilerin daha çok olumsuz görüş bildirdiği ancak uzaktan eğitime yönelik olumlu görüşlerinin de olduğu görülmektedir. Bu nedenle, probleme dayalı uzaktan eğitimin Fen laboratuvarı ve benzeri uygulamalı derslerde harmanlanmış şekilde uygulanması öğrenciler açısından olumlu olarak görülmektedir. Ayrıca, uzaktan eğitimin olumsuz yönlerinin önceden belirlenerek veya bu çalışma sonuçları ele alınarak pandemi dönemi gibi beklenmeyen dönemlerde eğitimin devam etmesi için geliştirilmesi ve yaygınlaştırılması öğrenciler ve eğitim açısından faydalı olacaktır.

Öğrencilerin WTPDÖ ölçeği ve harmanlanmış öğrenme ortamı ölçeği alt boyutlarının puanları arasındaki ilişki incelendiğinde iş birliğine dayalı öğrenme ile yüz yüze öğrenme arasında pozitif ilişkinin olduğu belirlenmiştir. Grup çalışmalarında iş birliğinin yüz yüze eğitimde web'e dayalı öğrenmeye göre daha fazla sağlandığı düşünüldüğünde yüz yüze eğitimin etkililiği ile iş birliğine dayalı öğrenmeye yönelik tutumun ilişkili olması beklenen bir sonuçtur. Ayrıca, web tabanlı öğrenmeye yönelik tutumun artmasıyla öğrencilerin hem çevrimiçi hem de harmanlanmış öğrenmenin etkililiğine yönelik puanlarının artması ve pozitif ilişkili olması beklenen bir diğer sonuçtur. Çünkü etkili bir çevrimiçi veya harmanlanmış öğrenme ortamına katılan öğrencilerin web tabanlı öğrenmeye yönelik olumlu tutumunun olması beklenir. Son olarak, korelasyon değerlerine göre teknik sorunların 
artmasıyla fen laboratuvarına yönelik tutumun ve Web'e dayalı öğrenmeye yönelik tutumun azaldığı belirlenmiştir. Web tabanlı öğrenme ortamlarının etkililiğini etkileyen en önemli etkenlerden biri de teknik altyapı ile ilgili sorunlardır. Öğrencilerin teknik destek alamadıkları ve bunun için iletişim kuramadıkları öğrenme ortamlarında derse ve web tabanlı öğrenmeye yönelik tutumlarının ve öğrenmenin etkililiğinin azaldığ görülmektedir (Soong, Chan, Chua ve Loh, 2001). Ayrıca, uzaktan eğitim ile yapılan derslerde öğrencilerin teknik sorunlardan dolayı motivasyonlarının düştüğü ve derse yönelik olumlu tutumlarının azaldığı belirlenmiştir (Turgut, 2011). Alan yazındaki çalışmalar ile yapılan çalışmanın sonuçları paralellik göstermektedir. Bu sonuçlar 1şı̆̆ında, probleme dayalı harmanlanmış öğrenmenin etkililiğinin arttırılması için iş birliğine dayalı öğrenme ortamının sağlanması ve teknik sorunlara yönelik önlem alınarak öğrencilerin web tabanlı öğretime yönelik tutumlarının geliştirilmesi gerekmektedir.

\section{SONUÇ ve ÖNERILER}

Sonuç olarak, pandemi sürecinde sağlık sorunları sebebiyle tüm dünyadaki ülkelerin yüz yüze eğitimi gerçekleştirememesinden dolayı uzaktan eğitim büyük önem kazanmıştır. Başta yükseköğretim kurumları olmak üzere tüm kademelerde ve neredeyse tüm ülkelerde uzaktan eğitime geçilmiştir. Ancak, uzaktan eğitim uygulamaları ülkelere, okul türlerine, kademelere ve diğer birçok özelliğe göre farklı şekillerde uygulanmaktadır. Pandemi nedeniyle uzaktan eğitime hızlı geçilmesi hem öğrencilerin hem de öğretmenlerin hazırbulunuşluklarının olmamasından kaynaklanan sorunlar gibi birçok plansız uygulamayı da beraberinde getirmiştir. Ancak, pandeminin birinci yılında Covid-19 virüsünün yayılmasına karşı birçok eğitim öğretim uygulaması da hayatta geçirilmiştir. Sadece uzaktan eğitimin kullanıldığı hem uzaktan eğitimin hem de yüz yüze eğitimin kullanıldığı harmanlanmış öğretim modelleri gibi birçok model uygulamaya konulmuştur. Bu nedenle, bu çalışma bulguları harmanlanmış öğrenme ortamı ve uzaktan öğrenme ortamının etkililiğini, öğrencilerin bu uygulamalara yönelik tutum ve görüşlerini belirleyerek gelecekte uygulanması muhtemel olan harmanlanmış öğrenme çalışmalarına işık tutmaktadır.

Bu bulgular ışığında probleme dayalı harmanlanmış öğrenme ortamlarının olumlu tutum geliştirdiği ve etkili olduğu görülmesine rağmen birçok olumsuz özelliğinin de uzaktan eğitimden kaynaklandığı görülmektedir. Bu olumsuz yönler dikkate alınarak eğitimde fırsat eşitsizliğinin kaldırılmasına yönelik teknik ve alt yapı çalışmalarının yapılması önerilebilir. Millî Eğitim Bakanlığının uzaktan eğitim sürecinde ihtiyaç sahibi ailelere yönelik 500.000 tablet dağıtması, internet altyapısının kötü olduğu yerlere internet altyapısının yapılması gibi projeler yapılarak teknolojik eksiklikler giderilebilir.

Öğrencilerin sınavların adil olarak yürütülmediğine yönelik görüşlerinin üstesinden gelebilmek için sınavların merkezi olarak eşit koşullarda yapılması sağlanabilir. İletişim eksikliği ve grup çalışmalarının etkisizliğini gidermek için öğrenciler arası çevrimiçi gruplar ve forumlar kurulabilir. Bu sayede hem iletişim hem de birlikte grup çalışması yapma fırsatı sağlanabilir. Öğrencilerin pandemi döneminde sağlık sorunları ve çok fazla iş yükü kaynaklı stres ve motivasyon düşüklügü yaşamasının önüne geçmek için bu süreçte ödevlerin ve iş yükünün azaltılması önerilmektedir. Ayrıca öğrencilerin aileleriyle yaşamaya başladıkları ve çalışma ortamlarının olmadığını ifade ettikleri belirlenmiştir. Bu yüzden öğrencilere uygun çalışma ortamlarının sağlanması önerilmektedir.

Öğrencilerin çoğunluğunun ilk kez uzaktan eğitim ve harmanlamış öğrenme deneyimine katılmalarından dolayı deneyimlerinin az olduğu ifade etmişlerdir. Ayrıca, öğrencilerin internet ve bilgisayar ile ilgili birçok teknik sorun yaşadıkları hem ölçeklerdeki maddelere verdikleri puanlardan hem de açık uçlu sorulara verdikleri cevaplardan elde edilmiştir. Gelecekte yapılacak olan harmanlanmış öğrenmeye dayalı çalışmalarda öğrencilerin bilgisayar ve internet ile ilgili deneyimlerinin ve yeterliliklerinin incelenmesi önerilmektedir.

Fen laboratuvar uygulaması dersinde probleme dayalı olarak gerçekleştirilen harmanlanmış öğrenme ortamına ilişkin öğrencilerin hem ölçeklerden aldıkları puanların orta değerin üstünde olduğu hem de açık uçlu sorularda çok sayıda olumlu görüş bildirdikleri görülmektedir. Bu nedenle probleme dayalı harmanlanmış öğrenmenin hem farklı kademlerde hem de farklı derslerde kullanılması önerilmektedir.

|Manisa Celal Bayar University Journal of The Faculty of Education, 2021, Vol. 9, No. 1| 
KAYNAKÇA

Akgündüz, D. (2013). Fen eğitiminde harmanlanmış öğrenme ve sosyal medya destekli öğrenmenin öğrencilerin başarı, motivasyon, tutum ve kendi kendine öğrenme becerilerine etkisi. (Yayınlanmamış Doktora Tezi). Marmara Üniversitesi Eğitim Bilimleri Enstitüsü, İstanbul.

Alper, A. \& Deryakulu, D. (2008). Web ortamlı probleme dayalı öğrenmede bilişsel esneklik düzeyinin öğrenci başarısı ve tutumları üzerindeki etkisi. Ĕ̆itim ve Bilim, 33(148), 49-63.

Alper, A. Y. (2003). Web ortamlı probleme dayalı öğrenmede bilişsel esneklik düzeyinin öğrenci başarısı ve tutumları üzerindeki etkisi. (Yayınlanmamış Doktora Tezi). Ankara Üniversitesi Eğitim Bilimleri Enstitüsü, Ankara.

Altunçekiç, A. (2010). Web destekli probleme dayal öğrenme ortamlarının bilişsel ve duyuşsal öğrenme ürünlerine etkisi: Gazi Üniversitesi Kastamonu Eğitim Fakültesi Örneği. (Yayımlanmamış Doktora Tezi). Gazi Üniversitesi Eğitim Bilimleri Enstitüsü, Ankara.

An, Y. J. (2006). Collaborative problem-based learning in online environments. (Unpublished Doctoral Dissertation). Indiana University, Department of Instructional Systems Technology, Indiana, USA.

Anderson, T. (2004). Toward a theory of online learning. In T. Anderson \& F. Elloumi (Eds.), Theory and practice of online learning (pp. 33-60). Athabasca, AB: Athabasca University.

Aydemir, S. (2012). Harmanlanmış öğrenme ortamının fen bilgisi öğretmen adaylarının bilimin doğası ve bilimsel araştırmayı anlamaları üzerine etkisi. (Yayınlanmamış Yüksek Lisans Tezi). Fırat Üniversitesi Eğitim Bilimleri Enstitüsü, Elâzı̆̆.

Bakioğlu, B., \& Çevik, M. (2020). Covid-19 pandemisi sürecinde fen bilimleri öğretmenlerinin uzaktan eğitime ilişkin görüşleri. Electronic Turkish Studies, 15(4), 109-129. https://dx.doi.org/10.7827/TurkishStudies.43502

Benigno, V., \& Trentin, G. (2000). The evaluation of online courses. Journal of computer assisted learning, 16(3), 259-270.

Bozkurt, A. (2020). Korona virüs (Covid-19) pandemi süreci ve pandemi sonrası dünyada eğitime yönelik değerlendirmeler: Yeni normal ve yeni eğitim paradigması. Açı öğretim Uygulamaları ve Araştırmaları Dergisi, 6(3), 112-142.

Cabı, E., ve Gülbahar, Y. (2013). Harmanlanmış öğrenme ortamlarının etkililiğinin ölçülmesi için bir ölçek geliştirme çalışması. Pegem Ĕ̆itim ve Öğretim Dergisi, 3(3), 11-26.

Can, E. (2020). Coronavirüs (Covid-19) pandemisi ve pedagojik yansımaları: Türkiye'de açık ve uzaktan eğitim uygulamaları. Açı öğretim Uygulamaları ve Araştırmaları Dergisi, 6(2), 11-53.

Çakın, M., \& Akyavuz, E. K. (2020). Covid-19 süreci ve eğitime yansıması: öğretmen görüşlerinin incelenmesi. International Journal of Social Sciences and Education Research, 6(2), 165-186.

Dağ, F. (2011). Harmanlanmış (karma) öğrenme ortamları ve tasarımına ilişkin öneriler. Ahi Evran Üniversitesi Ĕ̆itim Fakültesi Dergisi, 12(2). 73-97.

Delialioglu, O., \& Yıldırım, Z. (2008). Design and development of a technology enhanced hybrid instruction based on MOLTA model: Its effectiveness in comparison to traditional instruction. Computers $\mathcal{E}$ Education, 51(1), 474483.

Dursun, C. (2018). Sosyal medya destekli harmanlanmış öğrenme yönteminin öğrencilerin matematik başarılarına ve özyeterlilik algılarına etkisinin incelenmesi. (Yayımlanmamış Yüksek Lisans Tezi). Marmara Üniversitesi Eğitim Bilimleri Enstitüsü, İstanbul.

Emlek, B., \& Aktürk, A. O. (2017). Student views with regard to the web-based problem solving method. International Journal of Research in Education and Science, 3(1), 180-192.

Fresen, J. (2007). A taxonomy of factors to promote quality web-supported learning. International Journal on Elearning, 6(3), 351-362.

Gerber, M., Grund, S., \& Grote, G. (2008). Distributed collaboration activities in a blended learning scenario and the effects on learning performance. Journal of Computer Assisted Learning, 24(3), 232-244.

Graham, C. (2006). Blended learning systems: Definition, current trends and future directions. In C. Bonk \& C. Graham (Eds.), The handbook of blended learning: Global perspectives, local designs (pp. 3-21). San Francisco: Pfeiffer. 
Günbatar, M. S. (2009). Web tabanl probleme dayalı öğrenmenin öğrencilerin yaratıcı düşünme becerilerine ve tutumlarına etkisi. (Yayınlanmamış Yüksek Lisans Tezi). Yüzüncü Yıl Üniversitesi, Sosyal Bilimler Enstitüsü, Van.

Gürbüz, S., \& Şahin, F. (2014). Sosyal bilimlerde araştırma yöntemleri. Ankara: Seçkin Yayıncılık, (s 271).

Ho, V. T., Nakamori, Y., Ho, T. B. \& Lim, C. P. (2014). Blended learning model on hands-on approach for in-service secondary school teachers: Combination of e-learning and face-to-face discussion. Education and Information Technologies, 21(1),185-208.

Kadirhan, M. \& Korkmaz, Ö. (2020). The effects of learning blended with eba content on students' academic achievement and attitudes toward science course. Trakya Eğitim Dergisi, 10(1), 64-75.

Karabatak, S. \& Turhan, M. (2017). Effectiveness of web-based problem-based school administrator training program and its effect on participants' attitudes towards web-based learning. Pegem Eğitim ve Öğretim Dergisi, 7(4), 663712.

Karasar, N. (2013). Bilimsel araştırma yöntemi (25. baskı). Ankara: Nobel Yayın Dağıtım.

Karatepe, F., Küçükgençay, N., \& Peker, B. (2020). Öğretmen adayları senkron uzaktan eğitime nasıl bakıyor? Bir anket çalışması. Journal of Social and Humanities Sciences Research, 7(53), 1262-1274.

Kaya, Z. (2014). Harmanlanmış öğrenmenin fen bilgisi öğretmen adaylarının küresel ısınma konusundaki teknolojik pedagojik alan bilgisi ve sınıf içi öğretim becerilerinin geliştirilmesi üzerine etkisi. (Yayımlanmamış Doktora Tezi). Furat Üniversitesi, Eğitim Bilimleri Enstitüsü, Elâzı̆̆.

Kiriş̧̧ioğlu, S. (2009). Fen laboratuvarı derslerinde harmanlanmış öğrenme etkinliğinin çeşitli boyutlarda incelenmesi. (Yayınlanmamış Yüksek Lisans Tezi). Celal Bayar Üniversitesi, Fen Bilimleri Enstitüsü, Manisa.

Konu, M. \& Gül, Ş. (2017). Biyoloji dersinde yaşam temelli probleme dayalı öğretim uygulamalarının tutum, motivasyon ve problem çözme becerilerine etkisi. Hasan Ali Yücel Eğitim Fakültesi Dergisi, 14(1), 127.

Mailizar, Almanthari, A., Maulina, S., \& Bruce, S. (2020). Secondary school mathematics teachers' views on e-learning implementation barriers during the COVID-19 Pandemic: The case of Indonesia. Eurasia Journal of Mathematics, Science and Technology Education, 16(7), 1-9. https://doi.org/10.29333/ejmste/8240

Means, B, Toyama, Y., Murphy, R. F., \& Baki, M. (2013). The effectiveness of online and blended learning: A metaanalysis of the empirical literature. Teachers College Record, 115(3), 1-47.

MEB (2020). Basın Açıklaması. https://www.meb.gov.tr/bakan-selcuk-koronaviruse-karsi-egitimalaninda-alinantedbirleri-acikladi/haber/20497/tr adresinden erişilmiştir.

Mercan, A. (2018). Üniversite öğrencilerinin uzaktan eğitim ile ilgili görüşleri ve hazırbulunuşlukları: Afyon Kocatepe Üniversitesi Fen Edebiyat Fakültesi örneği. (Yayınlanmamış Yüksek Lisans Tezi). Afyon Kocatepe Üniversitesi, Fen Bilimleri Enstitüsü, Afyon.

Osguthorpe, R.T \& Graham, C. R. (2003). Blended learning environments definitions and directions. The Quarterly Review of Distance Education, 4(3), 227-233.

Pesen, A. (2014). Harmanlanmış öğrenme ortamının öğretmen adaylarının akademik başarısına, ders çalışma alışkanlıklarına ve güdülenme düzeylerine etkisi. (Yayınlanmamış Doktora tezi). Dicle Üniversitesi, Eğitim Bilimleri Enstitüsü, Diyarbakır.

Pınar, M. A., \& Dönel Akgül, G. (2020). The opinions of secondary school students about giving science courses with distance education during the Covid-19 pandemic. Journal of Current Researches on Social Sciences, 10(2), 461486.

Rodrigues, M., \& Biagi, F. (2017). Digital technologies and learning outcomes of students from low socio-economic background: An analysis of PISA 2015. Publications Office of the European Union, Luxembourg, http://dx.doi.org/10.2760/415251.

Selim, H. M. (2007). Critical success factors for e-learning acceptance: Confirmatory factor models. Computers $\mathcal{E}$ education, 49(2), 396-413.

Shea, P., \& Bidjerano, T. (2010). Learning presence: Towards a theory of self-efficacy, self-regulation, and the development of a communities of inquiry in online and blended learning environments. Computers $\mathcal{E}$ Education, 55(4), 1721-1731. https://doi.org/10.1016/j.compedu.2010.07.017

So, H. J., \& Brush, T. A. (2008). Student perceptions of collaborative learning, social presence and satisfaction in a blended learning environment: Relationships and critical factors. Computers \& education, 51(1), 318-336.

|Manisa Celal Bayar University Journal of The Faculty of Education, 2021, Vol. 9, No. 1| 
Soong, M. B., Chan, H. C., Chua, B. C., \& Loh, K. F. (2001). Critical success factors for on-line course resources. Computers \& education, 36(2), 101-120.

Sulčič, V., \& Sulčič, A. (2007). Can online tutors improve the quality of e-learning. Issues in Informing Science and Information Technology, 4, 201-210.

Sungur Alhan, S., \& Şimşek, Ü. (2020). Fen bilimleri öğretmen adaylarının teknolojik pedagojik alan bilgileri üzerine harmanlanmış öğrenme ortamının etkisi: Özel Öğretim Yöntemleri-II. Kastamonu Ĕ̆itim Dergisi, 28(6), 23052318. https://doi.org/10.24106/kefdergi.704381.

Şendağ, S. (2008). Çeorimiçi probleme dayalı öğrenmenin öğretmen adaylarının eleştirel düşünme becerilerine ve akademik başarılarına etkisi. (Yayımlanmamış Doktora Tezi). Anadolu Üniversitesi, Eğitim Bilimleri Enstitüsü, Eskişehir.

Şimşek, E. (2009). Karma öğrenmenin fizik öğretmeni adaylarının bilgisayar, internet ve web tabanl öğretime yönelik tutumlarına etkisi. (Yayınlanmamış Yüksek Lisans Tezi). Hacettepe Üniversitesi, Fen Bilimleri Enstitüsü, Ankara.

Tekedere, H. (2009). Web tabanlı probleme dayalı öğrenmede denetim odă̆ının, öğrencilerin başarısına, problem çözme becerisi algısına ve öğrenmeye yönelik tutumlarına etkisi. (Yayımlanmamış doktora tezi). Gazi Üniversitesi, Eğitim Bilimleri Enstitüsü, Ankara.

Tsai, M. H. \& Tang, Y. C. (2017), Learning attitudes and problem-solving attitudes for blended problem-based learning, Library Hi Tech, 35(4), 615-628. https://doi.org/10.1108/LHT-06-2017-0102

Tseng, K. H., Chang, C. C., \& Lou, S. J. (2012). The process, dialogues, and attitudes of vocational engineering high school students in a web problem-based learning (WPBL) system. Interactive Learning Environments, 20(6), 547562.

Tseng, K. H., Chiang, F. K., \& Hsu, W. H. (2008). Interactive processes and learning attitudes in a web-based problembased learning (PBL) platform. Computers in Human Behavior, 24(3), 940-955.

Tuncer, M. \& Bahadır, F. (2017). Uzaktan eğitim programlarının bu programlarda öğrenim gören öğrenci görüşlerine göre değerlendirilmesi. Journal of Educational Reflections, 1(2), 29-38.

Turgut, Y. E. (2011). Video konferans yoluyla verilen derslerde verimliliğe etki eden faktörler. (Yayımlanmamış Yüksek Lisans Tezi). Karadeniz Teknik Üniversitesi, Fen Bilimleri Enstitüsü, Trabzon.

Usta, E. (2007). Harmanlanmış öğrenme ve çevrimiçi öğrenme ortamlarının akademik başarı ve doyuma etkisi. (Yayımlanmamış Doktora Tezi). Gazi Üniversitesi, Eğitim Bilimleri Enstitüsü, Ankara.

Yalman, M. \& Kutluca, T. (2013). Matematik öğretmeni adaylarının bölüm dersleri için kullanılan uzaktan eğitim sistemi hakkındaki yaklaşımları. Dicle Üniversitesi Ziya Gökalp Ĕ̆itim Fakültesi Dergisi, 21, 197-208.

Yılmaz, Ö. (2017). Fen öğretiminde harmanlanmış öğrenme: Genel Kimya dersi laboratuvar uygulaması. Erzincan Üniversitesi Ĕ̆itim Fakültesi Dergisi, 19(3), 72-85. https://doi.org/10.17556/erziefd.315041.

Yılmaz, Ö. (2017). Yükseköğretimde harmanlanmış öğrenme: Fen eğitimi dersi uygulamasına yönelik öğrenci görüşleri. Ĕ̆itim Araştırmaları ve Öğretmen Ĕ̆itimi, 133-142.

Yıldırım, A., \& Şimşek, H. (2005). Sosyal bilimlerde nitel araştırma yöntemleri. Ankara: Seçkin Yayıncılık.

YÖK (2020). Üniversitelerde uygulanacak uzaktan eğitime ilişkin açıklama. 30 Nisan 2020 tarihinde <www.yok.gov.tr> adresinden erişildi. 


\section{Extended Abstract}

\section{Introduction}

In this study, a rapid and unplanned transition to distance education was made in our country as in almost all countries in the world with the effect of the recent pandemic. However, there are few studies on how students and other stakeholders were affected in this rapid transition period. In this study, a blended education model was applied with the first Covid 19 case of the pandemic in our country and the transition to distance education in higher education institutions. It has been preferred in these blended education environments, as it allows to benefit from the opportunities provided by both face-to-face and distance education. Considering this extraordinary process, we are in, we have inevitably started distance education. However, when this process, which affects the whole world, is over, nothing will be the same, including the training programs implemented. Undoubtedly, one of the reflections of this situation on education is that besides the face-to-face education, distance education will also be included. As a matter of fact, the Council of Higher Education has made a decision that $30 \%$ of the courses in undergraduate programs can be given in the form of distance education, and then it has been completely transferred to distance education with the Ministry of Education (MEB, 2020; YÖK, 2020). In this context, it is thought that the study will contribute to the field in terms of setting an example of how we can integrate distance education, which we will integrate into our training practices in the period after the pandemic. In addition, when the literature is examined, no research has been encountered that examines student attitudes towards the effectiveness of both face-to-face and distance education within the scope of an applied lesson such as a science laboratory in science education, and student views towards distance education. Therefore, the aim of this study was to determine the effectiveness of blended learning in the implementation of the problem-based science laboratory course, and the attitudes and opinions of students towards web-based problem-based learning.

1. What is the effectiveness of blended learning compared to students in problem-based blended learning environment?

2. What are the attitudes of students in problem-based blended learning environment towards web-based problem solving?

3. What are the opinions of the students in the problem-based blended learning environment towards distance education?

\section{Method}

In this study, a single group post-test experimental model, which is one of the pre-experiment experimental designs, was used. In the study, the students were engaged in blended as a learning strategy and web-based problembased learning and face-to-face problem-based learning were applied as a learning environment. As a result of this application, students' attitudes, the effectiveness of blended learning and their views on distance education were investigated.

The participant group of this study consisted of 42 third grade students who attended the Science Teaching Laboratory Practices II course at the Science Education Department from a state university in the Aegean Region. 28 of the participants were women and 14 of the participants were men. Purposeful sampling method was used in sample selection (Gürbüz \& Şahin, 2014). Choosing the Science Teaching Laboratory Applications II course was due to the fact that the study group was easily accessible, suitable for group work and it was a practice-based course. All students attending the course participated in the study voluntarily.

Web-Based Problem Based Learning Attitude Scale, Blended Learning Environments Scale and Open-Ended Questions for Distance Education were used as measurement tools. In practice, face-to-face trainings were held with the students in the first seven weeks. While the students were given theoretical information about the Science laboratory in the face-to-face trainings, the students made experiments in the laboratory environment in the applied parts. In the experiments conducted in the laboratory, the students were divided into groups and a scenario related to a science topic was given each week.

|Manisa Celal Bayar University Journal of The Faculty of Education, 2021, Vol. 9, No. 1| 
Findings

At the end of the application process, it was revealed that the students had a positive attitude towards the application process according to the answers they gave to the web-based problem-based learning attitude scale. In addition, it was concluded that students have a positive attitude towards science laboratory lesson, collaborative learning, web-based learning, self-learning, and problem solving, which are the sub-factors of the web-based problem-based learning attitude scale.

The students found the blended learning environment as effective. In addition, when the scores of the subfactors of the blended learning environment effectiveness scale were examined, it was determined that the students got high scores from the Factors of Face-to-Face Learning Environments and Blended Learning Environments, and closer to the average on the Online Learning Environments and Technical Dimensions factors.

It was revealed from the codes and quotations in the student responses that students' negative opinions about distance education were more than their positive opinions. Students were able to re-watch courses for distance education, save time, improve the awareness of doing homework, ensure taking responsibility for their own learning, using technology adds professional experience, doing research provides more learning, ensuring the continuity of education in processes such as epidemics, being at home with the family, and providing socialization during the pandemic period. However, students had technical problems and internet-related problems in distance education, ineffective group work compared to face-to-face education, lack of communication, inequality of opportunity in education, lack of concentration, motivation, too much homework and workload stress, responsibility as much as face-to-face education. It has been determined that they see negatively in terms of not encouraging them to take online lessons, not being able to participate in online lessons and coming back, unfair exams, health problems, increased responsibilities of living with the family and lack of a working environment.

\section{Result and Discussion}

As a result, distance education has gained great importance due to the fact that countries all over the world cannot provide face-to-face training due to health problems during the pandemic process. Distance education has been introduced in all levels, especially in higher education institutions, and in almost all countries. However, distance education practices were applied in different ways according to countries, school types, grades, and many other features. The rapid transition to distance education due to the pandemic has brought many unplanned practices, such as problems arising from the lack of readiness of both students and teachers. However, in the first year of the pandemic, many educational practices were also survived against the spread of the Covid-19 virus. Many models such as blended teaching models using only distance education and both distance education and face-to-face education have been implemented. Therefore, the findings of this study shed light on the blended learning studies that are likely to be implemented in the future by determining the effectiveness of blended learning environment and distance learning environment, students' attitudes, and views towards these applications.

\section{Araştırmanın Etik İzinleri}

Yapılan bu çalışmada "Yükseköğretim Kurumları Bilimsel Araştırma ve Yayın Etiği Yönergesi” kapsamında uyulması belirtilen tüm kurallara uyulmuştur. Yönergenin ikinci bölümü olan “Bilimsel Araştırma ve Yayın Etiğine Aykırı Eylemler" başlı̆̆ı altında belirtilen eylemlerden hiçbiri gerçekleştirilmemiştir.

Etik değerlendirmeyi yapan kurul adı: Aydın Adnan Menderes Üniversitesi Rektörlüğü Eğitim Araştırmaları Etik Kurulu

Etik değerlendirme kararının tarihi: 09.07.2020

Etik değerlendirme belgesi sayı numarası: 36161 